\title{
REVIEW
}

\section{Herpes simplex virus 1 (HSV-1) for cancer treatment}

\section{Y Shen and J Nemunaitis}

\author{
Mary Crowley Medical Research Center, Dallas, TX, USA
}

\begin{abstract}
Cancer remains a serious threat to human health, causing over 500000 deaths each year in US alone, exceeded only by heart diseases. Many new technologies are being developed to fight cancer, among which are gene therapies and oncolytic virotherapies. Herpes simplex virus type 1 (HSV-1) is a neurotropic DNA virus with many favorable properties both as a delivery vector for cancer therapeutic genes and as a backbone for oncolytic viruses. Herpes simplex virus type 1 is highly infectious, so HSV- 1 vectors are efficient vehicles for the delivery of exogenous genetic materials to cells. The inherent cytotoxicity of this virus, if harnessed and made to be selective by genetic manipulations, makes this virus a good candidate for developing viral oncolytic approach. Furthermore, its large genome size, ability to infect cells with a high degree of efficiency, and the presence of an inherent replication controlling mechanism, the thymidine kinase gene, add to its potential capabilities. This review briefly summarizes the biology of HSV-1, examines various strategies that have been used to genetically modify the virus, and discusses preclinical as well as clinical results of the HSV-1-derived vectors in cancer treatment.
\end{abstract}

Cancer Gene Therapy (2006) 13, 975-992. doi:10.1038/sj.cgt.7700946; published online 7 April 2006

Keywords: herpes simplex virus; HSV-1; cancer; oncolytic virus; clinical; gene therapy

\section{Introduction}

There are two types of herpes simplex virus, type 1 and type 2 (HSV-1 and HSV-2), both belong to the Herpesviridae family, Alphaherpesvirinae subfamily. Herpes simplex virus type 2 is a common human pathogenic virus and is associated with sexually transmitted diseases. Herpes simplex virus type 1 is also a human pathogen, but is rarely associated with genital area infection. Acute HSV-1 infection generally involves gingivo stomatitis. ${ }^{1}$ Chronic HSV-1 infection has also been described and is characterized by a skin keratitis. ${ }^{1}$ Following primary infection, HSV-1 follows a retrograde course along sensory nerves to reach dorsal lumbar sarcral ganglia. It may remain in a latent stage until occurrence of decreased immunity, at which point productive virus replication resumes. Subsequently, viral progenies travel along nerve pathways to previously involved sites in the skin or mucus membrane, causing a new round of infection. Small fluid-filled vesicles transiently develop. Duration of infection can be minimized with antiviral therapy such as acyclovir (ACV). Herpes simplex virus is capable of replicating in a wide variety of tissues, including lymphocytes. As a result of its intracellular locus of replication, it is able to escape

Correspondence: Dr J Nemunaitis, Mary Crowley Medical Research Center, 1717 Main Street, 60th Floor, Dallas, TX 75201, USA.

E-mail: jnemunaitis@mcmrc.com

Received 23 September 2005; revised 19 December 2005; accepted 8

January 2006; published online 7 April 2006
anti-HSV antibodies during the replication process. Herpes simplex virus type 1 genomic components controlling pathogenicity have been identified.

Herpes simplex virus type 1 has also been increasingly explored in cancer therapy. In this review, we will first describe the basic biology of HSV-1, followed by a discussion on strategies for HSV-1 vector engineering, and then focus on various applications of HSV-1 vectors in cancer therapies. We will review the most prevalent gene modified HSV-1 vectors in details and discuss properties of HSV-1, which enable its use as a unique gene delivery vehicle and/or oncolytic viral therapy.

\section{An overview of herpes simplex virus type 1 biology}

\section{Virion structure}

Herpes simplex virus type 1 is an enveloped doublestranded DNA (dsDNA) virus. Mature HSV-1 virion consists of four elements: (1) An electron-opaque core that contains the dsDNA genome wrapped as a toroid or spool. (2) An icosadeltahedral capsid surrounding the core. The capsid is composed of 162 capsomers arranged in a $\mathrm{T}=16$ icosahedral symmetry. The capsid contains channels, which are controlled by tegument proteins, thus controlling the transport of DNA through the channel. ${ }^{2}$ (3) An amorphous tegument surrounding the capsid. The tegument is largely unstructured and contains a matrix of proteins that play many important functions during HSV-1 infection. (4) An outer envelope exhibiting spikes on its surface. The envelope consists of a lipid bilayer with about 13 different viral glycoproteins embedded in it. 
Majority of the proteins of the mature virions are encoded by the viral genome, which consists of $152 \mathrm{~kb}$ of linear dsDNA arranged as the $\mathrm{L}$ (long) and the $\mathrm{S}$ (short) components that are covalently linked. Each component consists of unique sequences bracketed by inverted repeats (see Figure 1). The unique long segment $\left(\mathrm{U}_{\mathrm{L}}\right)$ is flanked by $a b$ and $b^{\prime} a^{\prime}$ repeated sequences, and the unique short segment $\left(U_{S}\right)$ is flanked by ac and $c^{\prime} a^{\prime}$ repeated sequences. Homologous recombination between the terminal repeats results in the inversion of the $\mathrm{L}$ and $\mathrm{S}$ components of HSV-1 genome, yielding four linear isomers at equimolar concentrations (Figure 1). The isomers are designated as $\mathrm{P}$ (prototype), IL (inversion of the L component), IS (inversion of the $\mathrm{S}$ component), and ISL (inversion of both $\mathrm{L}$ and $\mathrm{S}$ components). Herpes simplex virus type 1 genome encodes approximately 90 unique transcription units (genes), approximately half of which are essential for viral replication in a permissive tissue culture environment. The rest are dispensable for growth in cells in culture. However, these so-called 'nonessential' genes are most probably not dispensable for replication in animal system. They often encode functions that are involved in virus-host interactions, for example, inducing immune evasion and host cell shut-off.

\section{Cell entry}

To initiate infection, the virus first attaches to cell surface receptors. Fusion of the viral envelope with the cell membrane rapidly follows the initial attachment. The deenveloped tegument-capsid structure is then transported to the nuclear pores, where DNA is released into the nucleus. The initial attachment involves the interaction of viral envelope glycoproteins (such as $\mathrm{gC}$ and $\mathrm{gB}$ ) with the glycosaminoglycan moieties of cell surface heparin sulfate. ${ }^{3-5}$ Subsequently, viral glycoprotein gD binds one of several cell surface receptors (such as nectin-1a and nectin-1b, 2a, 2d, HveA), resulting in commitment to virion-cell fusion. ${ }^{6}$ Many of the receptors are broadly expressed in a wide variety of human cell types and tissues. Thus, HSV-1 has a very wide host range. Fusion of viral envelope with cell membrane occurs after the binding of $\mathrm{gD}$ to its cognate cell surface receptor. Three other HSV-1 glycoproteins, $\mathrm{gB}, \mathrm{gH}$ and $\mathrm{gL}$, have been implicated in the fusion step. ${ }^{7-9}$ The transition from attached to penetrated virus is very rapid and occurs within minutes. ${ }^{10}$ The capsid with associated tegument structures is then transported to the nuclear pore through the microtubular network. ${ }^{11}$

\section{Replication and progeny production}

Transcription, replication and packaging of HSV-1 genome take place in the nuclei of the infected cells. During productive infection, more than $80 \mathrm{HSV}-1$ genes are expressed in a tightly regulated manner (reviewed in reference Roizman and $\mathrm{Knipe}^{12}$ ). Viral DNA is transcribed by host RNA polymerase II, but various viral factors are involved at all stages of infection to ensure that viral genes are expressed in a coordinately regulated and sequentially ordered manner. Upon entering nuclei, viral genome circularizes and transcription of the five immediate-early (IE) genes, ICP0, ICP4, ICP22, ICP27 and ICP47 commences immediately. ${ }^{13} \mathrm{~A}$ number of cellular transcription factors and a viral tegument protein that is transported to the nucleus along with the viral genome, VP16, stimulate the transcription of the IE genes. Meanwhile, host gene transcription, RNA splicing and transport, and protein synthesis are inhibited (a phenomenon known as host cell shut-off) to facilitate the transition from cellular to viral gene expression. Most of the IE gene products are involved in transcription regulation and stimulate expression of other HSV genes. Expression of the early (E) viral genes, which primarily encode enzymes involved in nucleotide metabolism and viral DNA replication, occurs before the onset of viral DNA synthesis and requires the presence of the IE gene products. Viral E gene products (including the viral DNA polymerase, single-stranded DNA-binding protein, originbinding protein, DNA helicase-primase) localize into the nucleus and assemble onto the parental viral DNA, and start viral DNA synthesis in sub-nuclear structures called replication compartments. HSV-1 DNA replication involves origin-dependent initiation. ${ }^{14}$ There are three DNA replication origins in the viral genome, binding of these origin sequences by viral origin-binding protein (OBP) separates the DNA strands and initiate viral DNA synthesis. Viral DNA synthesis uses a rolling-circle mechanism, for the most part, producing 'head-to-tail' concatemeric molecules. ${ }^{15}$ Once viral DNA replication

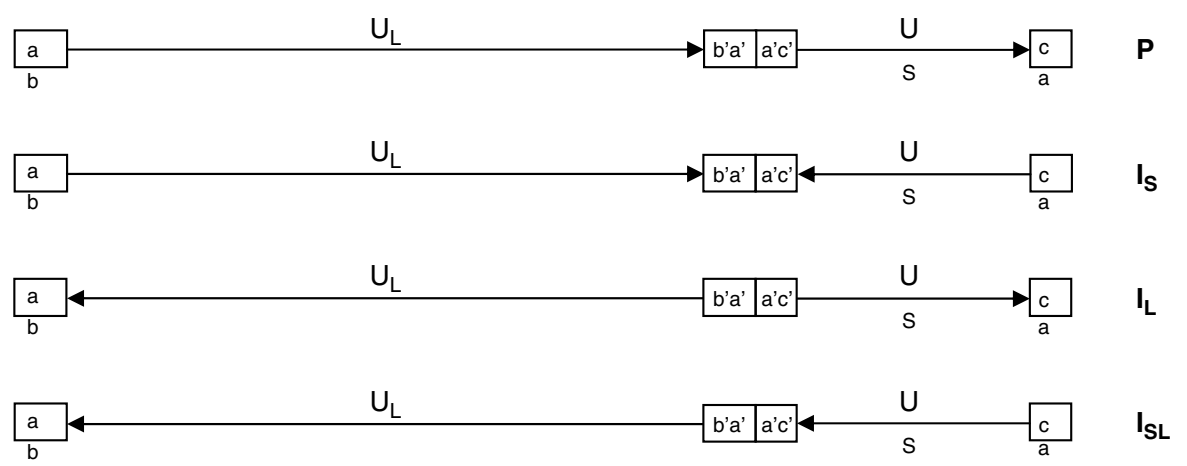

Figure 1 Diagram of HSV-1 genome. UL: unique long sequence. $U_{S}$ : unique short sequence. $a, b, c, a^{\prime}, b^{\prime}$ and $c^{\prime}$ indicate the terminal repeat sequences. Arrows indicated the orientation of $U_{L}$ and $U_{S}$. 
has initiated, expression of late (L) genes commences, which mainly produces structural components of the virion.

Mature HSV-1 virions are formed in well-organized steps including capsid assembly, encapsidation of viral DNA in preformed capsids, and virion egress through Golgi apparatus. ${ }^{16,17}$ Initial stages of capsid assembly probably occur in the cytoplasm, where some capsid proteins become associated with one another. ${ }^{18}$ These protein complexes are then translocated into the nucleus where final assembly of capsids occurs. After capsid assembly, progeny DNA concatemers are cleaved into unit-length monomers, and the monomers are inserted into the preformed capsids. ${ }^{19}$ Two cis-acting elements on viral DNA, pac1 and pac2, are required for precise cleavage and packaging of the HSV-1 genome. ${ }^{20}$ After encapsidation of full-length viral genomic DNA, the nucleocapsids mature by budding through nuclear membrane and processing through Golgi stacks (a process known as egress). The tegument layer and the virion envelope are acquired during this process. The enveloped particles are then released through secretory vesicles. HSV-1 replicates efficiently: in fully permissive tissue culture cells, the entire replication cycle takes about $18-20 \mathrm{~h}$.

\section{Lytic infection vs latency}

Herpes simplex virus type 1 is a neurotropic virus. After initial lytic replication in epithelia of the primary lesion, the viral progenies enter sensory neurons whose axon terminals innervate the affected area. The nucleocapsid and tegument are transported retrogradely along axons from the site of entry to the neuronal soma, where viral DNA and VP16 enter the nucleus. At this point, the virus may either initiate lytic replication or enter the latent state. ${ }^{21}$ Lytic replication, as described above, results in neuronal cell death and release of viral progenies. On the other hand, latently infected neuronal cells stay alive, and HSV-1 latency sometimes lasts the lifetime of the host. $^{22,23}$ During latent infection of HSV-1, the viral genome persists as a stable episomal element without detectable expression of IE, E or L gene products. Only a set of non-translated RNA species, known as the latencyassociated transcripts (LATs), are synthesized during latency. $^{24-27}$ The LAT gene is located within the inverted repeat sequence that brackets the unique long segment, therefore, there are two copies of LAT gene in each HSV1 genome. This gene encodes an $8.5 \mathrm{~kb}$ transcript that is present at low abundance (minor LAT). Splicing of this transcript produces a series of highly stable introns (major LATs) that accumulate to high levels within the nuclei of latently infected neurons. Expression of LATs is a hallmark of HSV-1 latency, although the LAT genes are not absolutely required for establishment or maintenance of latency. ${ }^{28-31}$ The LATs do not code for any protein and their role in HSV-1 latency remains unclear. However, a number of putative functions have been suggested (reviewed in Kent et al. ${ }^{32}$ and Bloom ${ }^{33}$ ).

In a fraction of neurons harboring latent HSV-1, the virus is periodically reactivated. Cascade expression of the viral IE, $\mathrm{E}$ and $\mathrm{L}$ genes resumes, resulting in the production of mature virions. Infectious virus particles are transported to the peripheral nerve terminals by anterograde axonal transport pathway, released, and infect cells at or near the site of initial infection. ${ }^{34}$ Reactivation is not completely understood, but external stimuli, such as UV light, stress and fever, are known for decades to induce HSV-1 reactivation. Depending on several factors, including the host immune status, the reactivation may be asymptomatic or lead to a recurrent lesion, which may vary considerably in severity from punctuate lesions that are invisible to naked eyes to severe, debilitating lesions in immunocompromised individuals.

\section{Interaction with host defense mechanisms}

During infection of humans, HSV-1 may cause many diseases include primary and recurrent epithelial lesions as well as disseminated disease and encephalitis. Complications caused by HSV-1 are of particular concerns in immunocompromised individuals or in newborn children. Like many other viruses, HSV-1 encodes a number of functions that block host defense against infection. These functions include: (1) blocking de novo synthesis of cellular proteins that may adversely affect viral replication; (2) bypassing RNA-dependent protein kinase (PKR) pathway; (3) inhibiting apoptosis; ${ }^{35}$ (4) inhibition of MHC class I peptide presentation on infected cells; ${ }^{36,37}$ and (5) blocking maturation of and antigen presentation by dendritic cells.

Blocking of host protein synthesis, known as host cell shutoff, is mediated by three mechanisms: degradation of host mRNA, selective degradation of cellular proteins, and inhibition of de novo host cell transcription and RNA processing. Degradation of host mRNA is mediated by a HSV-1 tegument protein encoded by the $\mathrm{U}_{\mathrm{L}} 41$ gene. ${ }^{38}$ The available evidence suggests that $U_{L} 41$ protein is either itself a ribonuclease (RNase) or able to activate a cellular nuclease. This protein is abundantly present in mature HSV-1 virions, and is carried into cells during infection, causing RNA degradation before any viral gene expression. Herpes simplex virus type 1 also induces targeted degradation of a subset of cellular proteins, a process that is mediated by several viral proteins including ICP0, ICP22 and the $\mathrm{U}_{\mathrm{L}} 13$ protein kinase. $^{39,40}$ In addition, HSV-1 suppresses host gene transcription and RNA splicing during the initial stages of infection. The former is caused by direct modification of RNA polymerase II by viral ICP22 and $\mathrm{U}_{\mathrm{L}} 13$ protein kinase, ${ }^{41}$ whereas the latter is mediated by ICP $27 .{ }^{42}$

One of the principal host defense mechanisms is mediated by PKR. RNA-dependent protein kinase is induced, via interferon $\alpha$ pathway, by double-stranded RNA (dsRNA) that forms during viral replication. Activated PKR causes the phosphorylation and inactivation of the translation factor eIF- $2 \alpha$, resulting in a total shutdown of protein synthesis required for viral replication. Many viruses (for example, human adenovirus) have evolved strategies to inhibit PKR activity in order to allow viral replication. Herpes simplex virus type 1, 
however, bypasses PKR-mediated host defense in a unique manner. Rather than inhibiting PKR activity, the viral ICP34.5 protein (also known as $\gamma-34.5$ or $\gamma_{1}-34.5$ protein) directly binds cellular protein phosphatase $1 \alpha$ and redirects it to dephosphorylate eIF-2 $\alpha$, resurrecting the translational activity of eIF-2 $\alpha^{43-45}$ Herpes simplex virus type 1 strains that lack ICP34.5 function are severely compromised in their ability to replicate in neurons. Such strains are unable to induce significant neurovirulence even when they were injected in high amounts into the central nervous system (CNS). ${ }^{43,46,47}$

Interaction between HSV-1 and the host immune system is very complex; many factors may influence the outcome. Both nonspecific (mediated by macrophages and natural killer cells) and specific immune responses (mediated by $\mathrm{B}$ and $\mathrm{T}$ cells) have been implicated as important host defenses against HSV-1 infections. ${ }^{48-53}$ The relative value of each of these defense mechanisms varies significantly according to the genetic background of the host ${ }^{54,55}$ and the route of viral inoculation. ${ }^{56}$ Herpes simplex virus type 1 has also evolved a number of strategies to interfere with dendritic cell maturation and antigen presentation mediated by dendritic cells (reviewed in Kobelt et al. ${ }^{57}$ and Pollara et al. ${ }^{58}$ ). Nevertheless, herpes simplex virus triggers strong cellular and humoral immunity. In general, cell-mediated immune responses are particularly important for viral clearance, ${ }^{56,59,60}$ as demonstrated by immunodepletion studies, ${ }^{52,61}$ adoptive transfer experiments ${ }^{53,62-64}$ and human clinical trials. ${ }^{60}$ It is intriguing that recurrent HSV-1 lesions can occur in the presence of both humoral and cell-mediated immunity, although duration of recurrent lesions is typically shortened compared to the original infection.

\section{Different ways of using herpes simplex virus type 1 for the treatment of human cancers}

Broadly speaking, there are two types of HSV-1 vectors, both have been used in cancer treatment. (1) Replicationdefective vectors, in which transgene expression cassettes are inserted in a viral genome with one or a few essential viral genes deleted. Such vectors can effectively express transgene products, but are unable to replicate, except in cells that complement the deleted viral functions in trans. A special group of replication-defective HSV vectors are amplicons. ${ }^{65-68}$ In this approach, an expression cassette for the therapeutic transgene(s) is placed in a plasmid ('amplicon' plasmid) that contains the viral packaging/ cleavage signals and HSV-1 origin of replication. Defective HSV-like particles that contain concatemerized plasmid DNA is produced in eukaryotic cells that supply viral functions in trans. (2) Conditionally replicating vectors, in which deletion of some nonessential viral genes results in viruses that preferentially infect, replicate in, and lyse tumor cells. Conditionally replicating vectors can also be modified to carry therapeutic transgenes to augment antitumor effects. This review focuses on the recent progress in using replication-defective and con- ditionally replicating HSV-1 vectors for the treatment of human cancers.

\section{Replication-defective herpes simplex virus type 1 vector-mediated cancer gene therapy}

A number of features make HSV-1 an attractive vector for cancer gene therapy. First, despite its neurotropism, HSV-1 possesses the ability to infect a wide range of host cells. Second, HSV-1 is highly infectious, able to transduce nondividing as well as dividing cells, and express transgene products with excellent efficiency. Third, as much as $30 \mathrm{~kb}$ of the HSV genome can be deleted and replaced by transgenes in replication-defective HSV-1 mutants, allowing for simultaneous delivery of multiple transgenes and use of heterologous promoters. Fourth, HSV-1 genome does not integrate into the cellular genome, eliminating the concern of insertional mutagenesis, as is the case for retrovirus and adenoassociated virus (AAV) vectors. Lastly, recombinant HSV-1 can be readily constructed, and purified stocks of virus containing $10^{10}$ infectious particles per milliliter can be prepared routinely without contamination of wildtype virus.

\section{Generation of replication-defective herpes simplex virus} type 1 vectors

Generation of replication-defective vectors can be accomplished by disruption of one or several essential IE genes. ${ }^{69,70}$ For example, vectors with ICP4 deletion are unable to replicate in non-complementing cells, and can be safely injected into the rat CNS. ${ }^{70}$ However, since ICP4 negatively regulates other IE genes such as ICP22, ICP27 and ICP0, infection with an ICP4-null mutant results in overexpression of these other genes, whose products are toxic to the host cells. ${ }^{70,71}$ To prevent such toxicity, a series of recombinant HSV-1 vectors have been generated that harbor various combinations of IE gene deletions. ${ }^{72-74}$ A mutant with all five IE genes (ICP0, ICP4, ICP22, ICP27 and ICP47) deleted has been produced, and was shown to be entirely nontoxic to cells. ${ }^{73}$ Other strategies to block replication and/or spread of HSV-1 include elimination of virion protein VP16 $6^{75-77}$ and deletion of the gH gene. ${ }^{78,79}$ These strategies, combined with deletion of IE genes, produce nontoxic, nonreplicative HSV-1 mutants that serve as safe delivery vehicles for antineoplastic genes to such cancer types as malignant glioma where tumor cells and normal cells are highly intertwined.

Cancer gene therapy using replication-defective herpes simplex virus type 1 vectors

The neurotropic nature of HSV-1 makes it an attractive vector for treatment of cancers of the CNS, such as malignant gliomas. Malignant glioma is a common, fatal malignancy of the CNS with a medium survival of 4-12 months following diagnosis. ${ }^{80}$ An invasive tumor margin of malignant gliomas, along with sensitive local environment, makes it nearly impossible to completely remove 
the tumor mass by surgery. Malignant gliomas are generally localized; distant metastasis occurs only under unusual circumstances. $^{81,82}$ This trait enables direct inoculation of the tumor with recombinant vectors. In addition, transient high-level expression of transgenes may be desirable to eradicate tumor cells, obviating the need for long-term expression. These make HSV-1 vectors attractive for the gene therapy of malignant gliomas.

Cancer gene therapy mediated by HSV-1 vectors has largely focused on the delivery of suicide genes. ${ }^{83}$ The most frequently used suicide gene is the native HSV-1 thymidine kinase $(\mathrm{TK})$ gene, encoded by $\mathrm{U}_{\mathrm{L}} 23$. In normal replication cycle of $\mathrm{HSV}-1$, TK is involved in synthesis of deoxyribonucleotides to facilitate viral DNA replication in cells with suboptimal precursor pools. ${ }^{84-86}$ In relation to suicide gene therapy, TK can convert nontoxic prodrugs such as ganciclovir (GCV) and ACV into cytotoxic metabolites that are incorporated into replicating DNA and cause premature termination to DNA synthesis. Thus, the TK suicide gene therapy is toxic to cells undergoing active DNA replication (such as cancer cells) but not towards neurons and quiescent glia. Earlier studies using replication-defective HSV-1 aimed at TK gene delivery have demonstrated antitumor activity in vitro and in animal models carrying human glioma. ${ }^{87,88} \mathrm{It}$ should be pointed out that in these experiments, TK gene expression was driven by a HSV-1 IE promoter (such as ICP4 promoter) or an exogenous promoter (such as cytomegalovirus IE promoter), rather than its own promoter. This is necessary because in a replicationdefective HSV-1 vector, many of the IE gene products are not available to activate transcription of TK gene, which is an early $(\mathrm{E})$ class gene.

It has been well established that $\mathrm{TK} / \mathrm{GCV}$ suicide gene therapy generates bystander cytotoxic effect, that is, tumor lysis greatly exceeds the degree of transduction. ${ }^{89,90}$ Several mechanisms may be responsible for the bystander effects, such as necrosis-induced inflammation and disruption of tumor vasculature. ${ }^{91}$ However, the most important may be passage of activated GCV (cytotoxic metabolites) from the HSV-TK transduced cell to its neighboring cells through gap junctions. This passage enables lysing of surrounding cancer cells that are not transduced. Gap junctions play a critical role in TK/GCV bystander effect. ${ }^{92}$ Gap junctions are intercellular channels formed by connexin molecules, one of which is connexin-43. ${ }^{93,94}$ Gliomas are often defective in connexin43 expression and thus have defective gap junctions, limiting the passage of activated GCV. To maximize the bystander effect in such tumors, connexin-43 gene was incorporated into the HSV-1 vector. ${ }^{95,96}$ It was hypothesized that expression of connexin-43 could restore gap junctions and thereby facilitate dissemination of activated GCV through cell membrane. Studies in animal models demonstrated that connexin-43 by itself had an antitumor effect that was comparable with that of HSV-TK/GCV. Importantly, the combination of $\mathrm{HSV}-\mathrm{TK} / \mathrm{GCV}$ and connexin-43 proved to have synergistic antineoplastic effect. $^{95,96}$
Cancer therapeutic genes other than TK have also been delivered using replication-defective HSV-1 vectors for the treatment of malignant gliomas and other types of cancer. These include $\mathrm{p} 53,{ }^{97}$ tissue inhibitor of metalloproteinases-2 (TIMP-2), ${ }^{98}$ IL-2, ${ }^{99,100}$ IL-12, ${ }^{101}$ IFN- $\gamma,{ }^{102}$ and granulocyte-macrophage colony-stimulating factor (GM-CSF). ${ }^{100,103}$ In general, these approaches have demonstrated promising antitumor potential following intratumoral injection in animal models. Furthermore, replication-defective $\mathrm{HSV}-1$ vectors have been used extensively for simultaneously delivery of multiple therapeutic genes. Examples are co-expressing TK and TNF$\alpha,{ }^{87,104} \mathrm{TK}$, connexin-43 and TNF- $\alpha,{ }^{105} \mathrm{TK}$ and IL-12, ${ }^{106}$ and $\mathrm{TK}$ and $\mathrm{I} \kappa \mathrm{B} \alpha{ }^{107}$ In these examples, significantly greater inhibition of tumor growth was achieved with vectors effecting multiple therapeutic modals compared to those that effect a single therapeutic modal.

However, more is not always better. A recent study tested a nonreplicating HSV-1 vector carrying two suicide genes, Escherichia coli cytosine deaminase (CD) and HSV-1 TK, followed by exposure with their reciprocal prodrugs (5-FC and GCV), in the 9L gliosarcoma model in vitro and in vivo. ${ }^{108}$ This double suicide gene therapy was shown to be inferior to single gene treatments, suggesting that HSV-1 TK and CD are mutually counteractive in the prodrug-dependent killing of glioma cells. Although a conclusive explanation for this observation is not yet available, this result raises the possibility that single suicide gene systems employing HSV-TK or CD may be preferable over combinations of the two. Whether the same conclusion may be applied to suicide gene combination remains to be determined.

\section{Conditionally replicating herpes simplex virus type 1 vectors as oncolytic agents}

The earliest report of using viruses to treat cancer was published 100 years ago. ${ }^{109}$ However, it is only recently that advances in molecular biology, virology and cancer biology has provided us with the tools necessary to develop novel oncolytic viruses for cancer therapy. The first tumor-selective oncolytic virus to demonstrate antitumor activity in a clinical setting was ONYX-015, a derivative of adenovirus type 5 with a deletion of the E1B$55 \mathrm{~K}$ gene. ${ }^{110-113}$ Since then, numerous viruses have been explored as tumor-selective replicating vectors, including adenovirus, HSV, vaccinia virus (VV), reovirus, Newcastle disease virus (NDV), vesicular stomatitis virus (VSV), measles virus, poliovirus and West Niles virus (reviewed in Chiocca, ${ }^{14}$ Kirn, ${ }^{115}$ Nemunaitis ${ }^{16}$ and Nemunaitis and Edelman ${ }^{117}$ ).

Efficient replication, cell lysis and spread of HSV-1, along with the virus' broad host range, make HSV-1 an attractive candidate for oncolytic viral agents. In permissive cells, the entire replication cycle of HSV-1 is usually completed within $20 \mathrm{~h}$, releasing thousands of progeny virions upon cell lysis. This is in contrast to adenovirus, whose replication cycle typically lasts $48-72 \mathrm{~h}^{118}$ 
Furthermore, it has been demonstrated that HSV-1 virions are capable of direct cell-to-cell spreading through cell junctions in addition to spreading through the extracellular space. ${ }^{119,120}$ This feature is extremely useful for an oncolytic virus, as it allows for efficient viral penetration within solid tumors with minimal systemic spread. Many of the limitations found with ONYX-015 in clinical trials, including insufficient antitumor potency as a single agent, inability to efficiently infect tumor metastases following intravenous (i.v.) delivery, insufficient virus spread within solid tumors, are, at least in part, due to slow replication of adenovirus. It is conceivable that these limitations can be relieved by viruses that are more potent in replication/spread. Other advantages of using HSV-1 vectors in oncolytic virotherapy include: (1) HSV-1 rarely produces life-threatening medical illness in immune-competent adults; (2) several anti-HSV-1 drugs (for example, ACV and famciclovir) have been approved to treat HSV-1 infection. ${ }^{121,122}$ Taking advantage of the natural presence of TK, these drugs inhibit HSV-1 replication and provide a safety mechanism to shut off viral replication should systemic toxicity ensue; and (3) HSV-1 productively infects cells from many laboratory animals. ${ }^{12}$ This makes HSV-1 easy to study in animal models, and preclinical results can be more readily translated into clinical trials. This is in contrast to, for example, oncolytic vectors derived from human adenovirus, for which a lack of good animal model has remained a major obstacle to preclinical evaluation.

\section{Strategies for creating replication-conditional herpes simplex virus type 1 vectors}

Many strategies have been used to create tumor-selective oncolytic viruses (reviewed in Nemunaitis and Edelman ${ }^{117}$ and $\operatorname{Kirn}^{123}$ ). These strategies can be grouped into three general approaches. The first approach is to delete gene functions that are critical for efficient viral replication in normal cells but are dispensable in tumor cells, exemplified by replication-selective adenovirus mutant ONYX015. ${ }^{110,124}$ Many replication-conditional HSV-1 vectors have included mutations and/or deletions in one or more of the genes encoding thymidine kinase, DNA polymerase, uracil DNA glycosylase, ribonucleotide reductase (RR), and ICP34.5. ${ }^{125}$ The second approach is to limit the expression of a critical viral gene to tumor tissues through the use of tumor- and/or tissue-specific promoters, represented by the adenovirus mutant CV706. ${ }^{126,127}$ The third approach is to alter viral tropism through modification of surface proteins. ${ }^{128,129}$ Thus far, all of these approaches have been successfully used to engineer tumor-specific herpesviruses.

\section{Single gene deletion}

Herpes simplex virus type 1 mutants with TK gene deletion were created and tested for oncolytic virotherapy. Intraneoplastic administration of the TK-deleted strains induced tumor regression in several animal tumor models, with severe necrosis of the tumor tissue. ${ }^{130-134}$ However, in tumor models in severe combined immunodeficient (SCID) mice, these mutants were shown to spread into normal tissues, ${ }^{135}$ indicating a lack of tumor specificity. This, along with concerns that lack of TK would render these mutants insensitive to treatment with the anti-viral drug ACV, has led to the development of many other replication-conditional $\mathrm{HSV}-1$ vectors.

A recombinant $\mathrm{HSV}-1$ with the $\mathrm{U}_{\mathrm{L}} 39$ gene deleted was examined (Table 1). The $\mathrm{U}_{\mathrm{L}} 39$ gene encodes ICP6, the large subunit of HSV-1 RR. Activity of RR is required for efficient viral DNA replication. ${ }^{136,137}$ The $\mathrm{U}_{\mathrm{L}} 39$-deleted virus, hrR3, is significantly attenuated for replication in normal cells but replicates efficiently in malignant cells. ${ }^{138-140}$ This virus has demonstrated selective replication in malignant tissues and has produced substantial antineoplastic effects and survival benefit in animal models of the brain, ${ }^{138,141,142}$ pancreas, ${ }^{143}$ colon $^{144}$ and liver cancers. ${ }^{145}$ Efficient replication of the viral vector is critical to its antineoplastic activity. ${ }^{4,50}$ The antitumor activity of hrR3 was enhanced by coadministration of cyclophosphamide (CPA). ${ }^{49,50}$ It was speculated that CPA, a strong immunosuppressive agent, may temporarily suppress systemic anti-viral immunity, allowing increased replication of the therapeutic virus and thus an enhanced antitumor effect. ${ }^{50}$ Depletion of complement via cobra venom factor (CVF) treatment also facilitated in vivo viral propagation and improved antitumor activity of hrR3. ${ }^{146}$

As mentioned above, ICP34.5 enables HSV-1 to replicate in neurons and has been described as a specific neurovirulence factor. ${ }^{43,46,47,147}$ There are two copies of ICP34.5 gene, because this gene is present in the inverted repeat region flanking the unique long segment. Several mutant strains of HSV-1 have been constructed in which both copies of the ICP34.5 gene were deleted (Table 1). These strains were replication-defective in neurons and other slow-growing cells, but replicate efficiently in rapidly dividing, transformed cells. ${ }^{148-151}$ In animal studies, the ICP34.5-deleted strains were shown to be nonvirulent when inoculated into the CNS of SCID mice, but replicated efficiently in xenograft tumors, induced tumor regression and significantly prolonged animal survival in treatment of glioma, ${ }^{152-155}$ mesothelioma, ${ }^{149}$ melanoma, ${ }^{150,151}$ ovarian cancer, ${ }^{156}$ and lung cancer ${ }^{157}$ in animal models. One of the ICP34.5-deleted strains, HSV1716, has been tested in clinical trials involving patients with recurrent high-grade glioma. Following intratumoral inoculation of doses up to $10^{5}$ plaque forming units (PFU), there was no induction of encephalitis, no adverse clinical symptoms, and no reactivation of latent HSV. ${ }^{158}$ Replication of the virus was demonstrated in human gliomas not only at the site of injection but also at distal tumor sites in some patients. ${ }^{159}$ In a recently published study, HSV1716 was injected into cavity following surgical resection of glioma tumor mass. No clinical toxicity associated with the administration of this virus was observed. The treatment has demonstrated survival benefit in a subset of patients and a reduction of residual tumor size in at least one patient. ${ }^{160} \mathrm{HSV} 1716$, developed by Crusade Laboratories (Glasgow, UK), is in clinical trials for treatment of glioma, melanoma, headand-neck cancer and mesothelioma. 
Table 1 Summary of oncolytic HSV-1 strains

\begin{tabular}{|c|c|c|c|c|c|}
\hline HSV-1 strain & Genetic alteration & $\begin{array}{l}\text { Therapeutic } \\
\text { transgenes }\end{array}$ & $\begin{array}{l}\text { Development } \\
\text { Stage }\end{array}$ & Clinical indications & Reference \\
\hline dlsptk & TK Gene deletion & None & Preclinical & & 130,135 \\
\hline hrR3 & $\begin{array}{l}\text { Disruption of UL39 (large subunit } \\
\text { of ribonucleotide reductase) }\end{array}$ & None & Preclinical & & $138,143-145$ \\
\hline HSV1716 & $\begin{array}{l}\text { 759-bp deletion in both copies of } \\
\text { ICP34.5 }\end{array}$ & None & $\begin{array}{l}\text { Human } \\
\text { clinical trials }\end{array}$ & $\begin{array}{l}\text { Glioma, melanoma, head- } \\
\text { and-neck cancer }\end{array}$ & $151,152,158-160,244$ \\
\hline R3616 & $\begin{array}{l}\text { 1000-bp deletion in both copies of } \\
\text { ICP34.5 }\end{array}$ & None & Preclinical & & $153,155,245$ \\
\hline R4009 & $\begin{array}{l}\text { Premature stop codon in both } \\
\text { copies of ICP34.5 }\end{array}$ & None & Preclinical & & $153,155,245$ \\
\hline G207 & $\begin{array}{l}\text { (1) } 1000 \text { bp deletion in both copies } \\
\text { of ICP34.5; } \\
\text { (2) Disruption of UL39 }\end{array}$ & None & $\begin{array}{l}\text { Human } \\
\text { Clinical trials }\end{array}$ & $\begin{array}{l}\text { Recurrent brain cancer } \\
\text { (glioma astrocytoma, } \\
\text { glioblastoma). }\end{array}$ & $166,167,169,170,184$ \\
\hline MGH-1 & $\begin{array}{l}\text { (1) } 1000 \text { bp deletion in both copies } \\
\text { of ICP34.5; } \\
\text { (2) Disruption of UL39 }\end{array}$ & None & Preclinical & & 142,165 \\
\hline $\begin{array}{l}\text { R7020 } \\
\text { (NV1020) }\end{array}$ & $\begin{array}{l}\text { (1) Deletion of one copy of } \\
\text { ICP34.5; } \\
\text { (2) TK under control of viral } \alpha 4 \\
\text { promoter, } \\
\text { (3) Deletion of UL24,UL55,UL56 }\end{array}$ & None & $\begin{array}{l}\text { Human } \\
\text { clinical trials }\end{array}$ & $\begin{array}{l}\text { Liver, metastases derived } \\
\text { from colorectal cancer }\end{array}$ & $185,186,188,192,194$ \\
\hline $\mathrm{G} 47 \Delta$ & $\begin{array}{l}\text { (1) } 1000 \text { bp deletion in both copies } \\
\text { of ICP34.5; } \\
\text { (2) Disruption of UL39 gene; } \\
\text { (3) Deletion of ICP47 gene. }\end{array}$ & None & Preclinical & & 195 \\
\hline Myb34.5 & $\begin{array}{l}\text { Deletion of both copies of } \\
\text { endogenous ICP34.5 } \\
\text { (2) Disruption of UL39 gene. } \\
\text { (3) Insertion of an ICP34.5 gene } \\
\text { under control of the B-myc } \\
\text { promoter }\end{array}$ & None & Preclinical & & 196,198 \\
\hline DF3y34.5 & $\begin{array}{l}\text { (1) Deletion of both copies of } \\
\text { endogenous ICP34.5 } \\
\text { (2) Insertion of an ICP34.5 gene } \\
\text { under control of the DF3/MUC1 } \\
\text { Promoter }\end{array}$ & None & Preclinical & & 200,201 \\
\hline HF10 & $\begin{array}{l}\text { (1) Spontaneously generated } \\
\text { clonal variant of HSV-1 }\end{array}$ & None & $\begin{array}{l}\text { Human } \\
\text { clinical trial }\end{array}$ & & 246,247 \\
\hline NV1042 & $\begin{array}{l}\text { (1) HSV-1/HSV-2 intertypic } \\
\text { recombinant } \\
\text { (2) Contains only one copy of the } \\
\text { ICP34.5 gene } \\
\text { (3) Deletion of UL56 and ICP } 47\end{array}$ & Murine IL-12 & Preclinical & & 215,217-219 \\
\hline $\begin{array}{l}\text { Onco Vex } \\
\text { CSF }\end{array}$ & $\begin{array}{l}\text { (1) Deletion of both copies of } \\
\text { ICP34.5 gene; } \\
\text { (2) Deletion of ICP } 47 \text {. }\end{array}$ & GM-CSF & $\begin{array}{l}\text { Human } \\
\text { clincal trials }\end{array}$ & $\begin{array}{l}\text { Breast cancer, head-and } \\
\text { neck cancer, Melanoma }\end{array}$ & 222,223 \\
\hline
\end{tabular}

\section{Multiple gene deletion}

Herpes simplex virus type 1 strains carrying deletion of a single gene often retain residual replication, and toxicity, in normal cells. ${ }^{161-163}$ Therefore, additional deletions or alterations have been made to the HSV-1 mutant strains described above to further increase the safety margin of the vectors as well as to decrease the likelihood of reversion to wild type. ${ }^{164}$ These strains are often referred to as the second-generation viruses to distinct them from the strains that contain deletions of a single viral gene. An important representative of the second generation oncolytic viruses is G207 (it should be noted that a nearly identical mutant, MGH-1, was constructed and tested separately by another group ${ }^{165}$ ). G207 contains deletions in both copies of ICP34.5 gene and a destructive insertion of $E$. coli lac $\mathrm{Z}$ gene in $\mathrm{U}_{\mathrm{L}} 39$ gene which encodes ICP6. ${ }^{166}$ It has been one of the most prominent herpes oncolytic vectors in both preclinical and clinical studies (Table 1). G207 has several favorable properties for treating human cancers: replication-competence in tumor cells, attenuated neurovirulence, temperature sensitivity, GCV hypersensitivity, and the presence of an easily detectable histochemical (lac $\mathbf{Z}$ gene product) marker. ${ }^{166}$ The safety of G207 has been tested extensively in animal models from mice to non-human primates. ${ }^{167-170}$ No virus-related toxicities was observed at doses as high as $10^{9} \mathrm{PFU}$ in monkeys, ${ }^{167}$ 
a sharp contrast to wild-type HSV-1 strains, which caused severe toxicity and animal death. G207 has demonstrated potent antineoplastic activity in many different cancer models, both in immunodeficient and immunocompetent animals. ${ }^{125,171-177}$ The existence of pre-existing anti-HSV-1 immunity has no measurable effect on the oncolytic activity of G207, and multiple injections can be applied without being affected by immune resistance to the virus. ${ }^{178,179}$ It appears that G207 inhibits tumor growth by two mechanisms: direct oncolysis via virus replication $^{166}$ and induction of tumor-specific immunity via an increase in cytotoxic T-cell (CTL) activity. ${ }^{172,180-183}$ Based on the promising preclinical data, G207 is now evaluated in clinical trials. Phase I clinical trials in patients with malignant glial tumors confirmed the safety of G207 virotherapy. No virus-related toxicity or herpes encephalitis was observed at doses of up to $3 \times 10^{9}$ PFU injected directly into the tumor. ${ }^{184}$ Radiographic and neuropathologic evidence suggested antitumor activity and long-term presence of viral DNA in some patients. Currently, MediGene AG (Frankfurt, Germany) is sponsoring further clinical development of G207 to assess its antitumor activity in patients with brain tumors.

Another HSV-1 mutant with multiple gene deletions, $\mathrm{R} 7020$, contains a $15-\mathrm{kb}$ deletion across the joint region of the long and short segments of the HSV-1 genome (thus deletion of one copy of ICP34.5) in addition to a deletion in the endogenous TK gene (Table 1). ${ }^{185}$ The long/short junction of R7020 contains a 5.2-kb fragment of HSV-2 DNA and an exogenous copy of the HSV-1 TK gene under the control of the powerful HSV-1 ICP4 promoter. Thus, R7020 remains sensitive to ACV and GCV. These genetic manipulations allow R7020 to replicate preferentially in neoplastic cells, resulting in a remarkable safety profile in extensive rodent and primate studies, as well as in limited human vaccine trials. ${ }^{185,186}$ Since one copy of the ICP34.5 gene is intact, R7020 replicated to much higher levels compared to the ICP34.5 double-deletion mutant R3616 both in vitro and in animal tumors. ${ }^{187}$ Its antitumor effect was significantly better than that of R3616. ${ }^{188-193}$ R7020 is now evaluated in clinical trials under the name of NV1020 (MediGene AG, Frankfurt, Germany). In a phase I trial, single doses of NV1020 were administered by the hepatic artery to 12 patients with colon carcinoma liver metastasis. ${ }^{194}$ Doses of up to $1 \times 10^{8}$ PFU were well-tolerated; all adverse events were reported as mild or moderate. Virological evidence suggested that NV1020 replicated in patient tumor tissues. Levels of the surrogate tumor marker carcinoembryonic antigen (CEA) declined in a subset of patients and there appeared to be anecdotal evidence of tumor regression or tumor stability on computerized tomography (CT) scan by day 28. Phase II clinical trials with NV1020 are ongoing.

Several other HSV-1 mutants with multiple gene deletions have been created and tested. G47D is a derivative of G207 that contains an additional deletion in the ICP47 gene. ${ }^{195}$ Because ICP47 is responsible for inhibiting the transporter associated with antigen presentation (TAP), ${ }^{36,37}$ its absence led to increased MHC class I expression in infected cancer cells, promoting tumor antigen presentation and antitumor immunity. G47 $\Delta$ was significantly more efficacious in vivo than its parent G207 at inhibiting tumor growth in both immunecompetent and immune-deficient animal models, while its animal safety profile was similar to that of G207. ${ }^{195}$

\section{Tumor-specific promoters}

Several oncolytic HSV-1 strains have been created by utilizing tumor-specific promoters. Myb34. $5^{196}$ was constructed by deleting both endogenous copies of the ICP34.5 gene and re-inserting this gene into the ICP6 locus under control of the $B-m y b$ promoter. This virus is similar to hrR3 in its preferential replication in actively dividing cells by virtue of the disrupted ICP6 gene. In addition, its replication is further regulated by the B-myb promoter, which is active in E2F-deregulated cells and in cycling cells. ${ }^{197}$ Compared to hrR3, Myb34.5 is more attenuated in normal cells both in vitro and in vivo. Its toxicity was greatly reduced in mice after i.v. administration. Cytotoxicity of Myb34.5 in tumor cells, however, was as robust as that of hrR3. ${ }^{198}$ A similar virus, DF $3 \gamma 34.5$, in which expression of ICP34.5 is controlled by DF3/MUC1 promoter/enhancer sequence, ${ }^{199}$ has shown preferential replication in tumors that express DF3/MUC1, restricted biodistribution, and reduced toxicity after systemic administration. ${ }^{200,201}$ Several other viruses have been constructed in which essential HSV-1 immediate-early genes (such as ICP4) are under the control of CEA promoter, ${ }^{200}$ albumin promoter, ${ }^{202,203}$ and calponin promoter. ${ }^{203,204}$ Replication of these viruses was shown to be restricted to cells that overexpress the respective proteins. These viruses are currently under preclinical examination.

\section{Vector re-targeting}

Vector re-targeting has been explored rather extensively as a unique strategy to increase tumor specificity of oncolytic adenoviral vectors. ${ }^{205}$ Although the complexities of HSV-1 entry are not fully unraveled, several studies have demonstrated the feasibility of restricting HSV-1 infection to predefined subpopulations of cells (reviewed in Burton et al. ${ }^{13}$ ). For example, an HSV-1 mutant was engineered in which the heparan sulfate binding domain of $\mathrm{gB}$ was abrogated, and $\mathrm{N}$-terminal truncated $\mathrm{gC}$ was fused to full-length erythropoietin (EPO). ${ }^{206}$ This virus strain showed greatly reduced glycosaminoglycan binding, as well as a new acquisition of specific binding to the EPO receptor. Although this virus is noninfectious and is not useful as the backbone of oncolytic viral vectors, it has demonstrated feasibility of HSV vector retargeting. ${ }^{206}$ Recently, more effective retargeted HSV vectors have been reported (for examples, see Argnani et al. ${ }^{207}$ and Zhou et al. ${ }^{208}$ ). A number of cell surface proteins were shown to be overexpressed in cancer cells, such as epidermal growth factor receptor (EGFR), ${ }^{209}$ folate receptor, ${ }^{210} \mathrm{CD} 44 .{ }^{211}$ It is reasonable to assume that engineered $\mathrm{HSV}-1$ vectors that specifically target these cell surface proteins will provide additional tumor selectivity for oncolytic viruses. 


\section{Armed oncolytic virus}

Because infection and lysis of $100 \%$ of the tumor cells is hard to achieve in vivo using oncolytic viruses alone, oncolytic viruses are often 'armed' with genes that can augment their cytolytic capacities. Meanwhile, successful cancer gene therapy requires high levels of transgene expression in a high percentage of tumor cells in vivo. Oncolytic viruses that specifically replicate in tumor tissues and amplify template copy number provide an ideal platform for achieving this goal. Oncolytic HSV-1 vectors have been used successfully to deliver immunoregulatory molecules, prodrug converting enzymes and angiogenesis inhibitors. $^{212}$

Synergism of antitumor effect was observed when oncolytic HSV-1 mutants were engineered to express cytokines. An elegant experiment done by Andreansky et $a .^{213}$ clearly demonstrated that cytokine expression may be an important adjunct to oncolytic HSV-1 therapy. IL-4 (an immunostimulatory cytokine) and IL-10 (an immunosuppressive cytokine) were separately inserted in a HSV-1 vector with both copies of ICP34.5 gene deleted. In a glioma model in immunocompetent mice, inoculation of these vectors produced dramatically opposite physiologic responses. The IL-4-expressing vector significantly prolonged survival of tumor bearers compared to the parental virus, whereas tumor-bearing mice that received the IL-10-expressing vector had a median survival that was identical to that of saline-treated controls. Numerous studies have shown that oncolytic HSV-1 vectors that express IL-12 have significantly greater antitumor efficacy compared to their counterparts, which do not carry an IL-12 gene. ${ }^{101,214-218}$ This additional antitumor effect appeared to be mediated by both induction of tumorspecific cytotoxic T-lymphocytes ${ }^{216,219}$ and inhibition of tumor angiogenesis. ${ }^{218}$ Expression of IL-2 from an amplicon vector also improved the overall antitumor effect of an oncolytic HSV-1 vector in a combination study. ${ }^{220,221}$ Overall toxicity of the oncolytic HSV-1 vectors was not altered by insertion and expression of the cytokine genes.

A genetically engineered strain of HSV-1, which expresses human immunostimulatory molecule GMCSF, has been created, preclinically tested and is now evaluated in clinical trials under the name of OncoVex ${ }^{\mathrm{GM}-\mathrm{CSF}}$ (BioVex Ltd, Abingdon, UK). Four modifications were incorporated into this virus (Table 1). ${ }^{222}$ First, a fresh clinical isolate of HSV-1 (JS1 strain) was used as the backbone for this virus instead of a laboratory strain which has been passaged numerous times in tissue cultures and may have partially lost their lytic capability in human tumor cells. Second, both copies of the ICP34.5 gene were deleted. Third, the viral ICP47 gene was deleted. Finally, human GM-CSF gene was inserted in this vector. It was reasoned that combination of GM-CSF with oncolytic therapy may be particularly effective as the necrotic cell death accompanying virus replication should serve to effectively release tumor antigens to induce a GM-CSF-enhanced immune response, resulting in systemic antitumor effects. OncoVex ${ }^{\mathrm{GM}-\mathrm{CSF}}$ was tested in vitro in human tumor cell lines and in vivo in mouse tumor models, both demonstrating promising antitumor effects. $^{222}$ In vivo, both injected and non-injected tumors showed significant shrinkage or clearance and mice were protected against re-challenge with the same tumor cells. In phase I clinical trials involving patients with solid tumors including breast cancer, head and neck cancer, and melanoma, OncoVex GM-CSF was shown to be well tolerated and substantial biological effects were observed. $^{223}$ Phase II studies with OncoVex ${ }^{\text {GM-CSF }}$ are now underway.

Others have identified use of oncolytic HSV-1 mutants to express prodrug-converting enzymes. For example, HSV1yCD was engineered such that the viral RR gene was disrupted by sequences encoding yeast cytosine deaminase (yCD), which metabolizes the prodrug 5fluorocytosine (5-FC) to 5-fluorouracil (5-FU). The combination of $\mathrm{HSV}-1$ replication and intratumoral conversion of $5-\mathrm{FC}$ to $5-\mathrm{FU}$ was more effective than either modality alone in treatment of mice with diffuse liver metastases, and significantly prolonged animal survival. $^{224}$ Similar results were obtained from rRp450, a replication-conditional HSV-1 mutant which does not express RR but carries the rat cytochrome $P 450$ transgene. Cytochrome $P 450$ activates prodrugs such as CPA to generate highly toxic metabolite. It was shown that rRp450-mediated oncolysis was enhanced by administration of CPA, both in tissue culture and in animal tumor models. ${ }^{145,225-227}$ Cyclophosphamide is an immunosuppressive agent. As discussed above, immunosuppression by CPA facilitates HSV-1 replication in vivo, thus enhancing the oncolytic effect of replication-competent HSV-1 vectors. However, enhancement of rRp450 antitumor effect appeared to be independent of the immunosuppressive property of CPA, as it was observed in immunodeficient mice as well. ${ }^{225,228}$

In contrast to $\mathrm{yCD} / 5-\mathrm{FC}$ and $\mathrm{p} 450 / \mathrm{CPA}, \mathrm{TK} / \mathrm{GCV}$ combination did not augment the antitumor efficacy of the oncolytic HSV-1 strains. Both HSV1yCD and rRp450 retain endogenous TK gene. When treated with GCV, antineoplastic efficacy of both viruses was reduced. ${ }^{145,224,227}$ These results were explained by the finding that activation of 5-FC and CPA only minimally affected HSV-1 replication, whereas activation of GCV markedly attenuated HSV-1 replication. ${ }^{224,227}$ Thus, combination of suicide gene therapy with oncolytic viral vectors must be evaluated carefully and on a case-by-case basis. Antiviral effect of GCV against HSV-1 strains that carry the TK gene may be used as a 'turn-off' safety valve if viral-related toxicity develops.

\section{Combination with other therapies}

Combination of oncolytic HSV-1 strains with chemotherapy or radiotherapy generally displays enhancement in antitumor activity. ${ }^{175,188,229-232} \mathrm{~A}$ variety of chemotherapy agents (mitomycin $\mathrm{C}$, cisplatin, methotrexate and doxorubicin) were shown to augment the antitumor effects of oncolytic virus HSV $1716 .^{231,233}$ Ionizing radiation was shown to enhance anti-cancer activity of hrR3 without significantly altering viral replication. ${ }^{234}$ Similarly, combination of ionizing radiation and the 
ICP34.5-deleted HSV-1 strain R3616 induced a synergistic antitumor response, resulting in better tumor regression and better survival rates. ${ }^{235,236}$ At least one report, however, indicated that ionizing radiation had no effect on antitumor activity of G207. ${ }^{237}$ It is possible that different genetic background of these mutants may cause these viruses to respond differently to chemo- and radiotherapy. More research is necessary to clearly define the interaction between radiation and oncolytic activity of viral vectors.

\section{Limitations of herpes simplex virus type 1 vectors}

Although extensive studies using HSV-1 vectors for cancer treatment have demonstrated remarkable safety and generated encouraging antitumor efficacy data, several limitations do exist for the HSV-1-derived vectors and may limit their usefulness. For example, multigene deleted HSV-1 vectors are in general more difficult to produce than the wild-type virus, resulting in lower yield. Complementing cell lines with multiple viral genes integrated must be generated and used to produce the mutant viruses, which adds another level of complexity. Long-term stability (over 6-month period) of HSV-1derived vectors, whether in aqueous solution or in lyophilized form, has not been adequately addressed. Induction of antiviral or antitransgene product immune response may reduce the effectiveness of $\mathrm{HSV}$-1-derived vectors, especially when multiple injections of the vectors are necessary. Although it has been shown that the existence of pre-existing anti-HSV-1 immunity has no measurable effect on the oncolytic activity of G207, and multiple injections can be applied without being affected by immune resistance to the virus, ${ }^{178,179}$ the impact of preexisting immunity on HSV-1 cancer gene therapy and virotherapy still needs to be carefully evaluated by further studies. More research in laboratory and in clinics would be required to address all these issues.

Herpes simplex virus type 1 is a human pathogen with broad cell type tropism and great replication capacity, so naturally, safety of HSV-1-based therapies is an important concern. In this review, we outline a wide variety of strategies that aim to minimize toxicity of HSV-1 vectors and prevent undesired damage to normal tissues. In spite of the impressive safety records with these agents in animal studies and in human clinical trials, therapies based on HSV-1 vectors (especially when replicationconditional viruses are used for virotherapies) still raise bio-safety and risk management issues. This is particularly important considering the potential of homologous recombination of recombinant viral genome with the latent wild-type HSV-1 present in a substantial human population and with viral DNA sequence in complementing cell lines. These are discussed in the following section.

\section{Safety considerations}

The properties that make HSV-1 a useful tool for cancer therapy also make it potentially dangerous to the treated patients and their contacts. For example, efficient replication of HSV-1 in a wide spectrum of human cells raises the possibility of serious damage to untargeted, normal tissues. This is particularly important when replication-competent viruses are employed in systemic administration. An increasing population with immunodeficiency also adds to the possibility of an epidemic spread of the virus. Because many recombinant HSV-1 vectors carry biologically active transgenes, effects of the transgene products must be considered in addition to the pathogenicity of the viral vectors. Extensive clinical studies are necessary to address these safety concerns.

A significant risk lies with the possibility of recombination. Homologous recombination could occur when a replication defective or a conditionally replicating HSV-1 vector infects a cell which already harbors a wild-type latent virus, homologous recombination between the incoming vector and the resident wild-type virus might occur and could result in the generation of a fully virulent virus that carries a biologically active gene. Although studies using animal models did not show a significant risk of wild-type virus re-activation, ${ }^{168,238}$ this possibility has not been clearly ruled out in human patients. This poses a significant risk not only to the individual who receives the treatment, but also to anyone who comes in contact with the person. To prevent this risk, it is essential to insert transgenes in regions of the viral genome that are essential for virus replication. This way, incorporation of the transgene(s) must result in inactivation of the recipient genome by disrupting the essential genes at the insertion loci. Recombination could also result from propagation of defective viruses in complementing cell lines, leading to the production of replication-competent viruses that could contaminate vector stocks. The way to avoid such recombination is by carefully designing the system so that there is no homology or minimal homology between the vector and the complementing sequence in the cell line. ${ }^{239}$

Should unwanted replications occur, methods for treating or controlling HSV-1 replication do exist (for a detailed review, see Villarreal ${ }^{240}$ ). As mentioned earlier, viral TK may be used as a safety valve when combined with prodrugs such as GCV, famciclovir, penciclovir, $\mathrm{ACV}$, and foscarnet. Inhibition of HSV-1 replication has been demonstrated using this approach both in vitro and in vivo. ${ }^{164,224,227}$

\section{Conclusions and future direction}

Herpes simplex virus-based vectors for cancer treatment exist in three forms: amplicon, replication-defective vectors and replication-conditional viruses. This review focuses on the recent progress using replication-defective vectors and replication-conditional viruses. While strategies using replication-defective HSV-1 to deliver therapeutic transgenes have yielded encouraging results, the fastest growing area in $\mathrm{HSV}-1$ vector-mediated cancer treatment lies with replication-conditional viruses. Not only do they provide a means to selectively target and kill 
cancer cells in their own right but they also are attractive vectors for tumor-specific delivery of multiple foreign antitumor gene products, making it possible to combine oncolysis of the viral vectors with antitumor effects of multiple transgenes to achieve synergistic tumoricidal effects. There is still much to be learned and to be improved, but currently available data have certainly indicated a promising perspective for HSV-1 and other virus-based therapies. Twenty years ago, cancer therapy with monoclonal antibodies faced many challenges ranging from safety to efficacy to manufacturing issues, not unlike the challenges that gene therapy and virotherapy are facing today. To date, eight monoclonal antibodies have been approved by FDA for treating human cancers, ${ }^{241}$ and a lot more are currently under clinical investigation. With active research in cancer biology, virology, immunology and the related field, we have reason to anticipate new therapies based on viral vectors in the future. As regards to HSV-mediated therapies, important issues currently under investigation to improve the efficacy and safety of include: evaluation and selection of the therapeutic transgenes, improvement of vector delivery efficiency and specificity. Further understanding of the biology of this virus will improve our ability to manipulate it to our advantage. Two approaches aimed at vector optimization deserve our attention: First, using fresh clinical isolates of HSV-1, rather than the laboratory strains which may have accumulate undesired genetic alterations, as the backbone for genetic engineering. ${ }^{222}$ Care must be exerted as these strains are conceivably more virulent, and thus posing a greater risk, than many of the lab strains. Alternatively, it is possible to isolate viral mutants with enhanced antitumor efficacy by serial passage of a laboratory strain in cancer cells under carefully designed conditions. ${ }^{242,243}$

\section{Acknowledgements}

We extend special thanks to Dr Sylvie Laquerre (ViroPharma, Inc., Exton, PA) for her critical reading of the manuscript.

\section{References}

1 Lerner AM. Infections with herpes simplex virus. In: Adams RD, Braunwald E, Petersdorf RG, Wilson JD (eds). Harrison's Principles of Internal Medicine. McGraw-Hill, Inc.: New York, 1980, pp 847-852.

2 Zhou ZH, Chen DH, Jakana J, Rixon FJ, Chui W. Visualization of tegument-capsid interactions and DNA in intact herpes simplex virus type 1 virions. J Virol 1999; 73: $3210-3218$.

3 Herold BC, WuDunn D, Soltys N, Spear PG. Glycoprotein $\mathrm{C}$ of herpes simplex virus type 1 plays a principal role in the adsorption of virus to cells and in infectivity. J Virol 1991; 65: 1090-1098.

4 Herold BC, Visalli RJ, Susmarskin N, Brandt CR, Spear PG. Glycoprotein $\mathrm{C}$-independent binding of herpes simplex virus to cells requires cell surface heparan sulphate and glycoprotein B. J Gen Virol 1994; 75(Part 6): 1211-1222.

5 Spear PG, Shieh MT, Herold BC, Wudunn D, Koshy TI. Heparan sulfate glycosaminoglycans as primary cell surface receptors for herpes simplex virus. Adv Exp Med Biol 1992; 313: $341-353$.

6 Spear PG. Herpes simplex virus: receptors and ligands for cell entry. Cell Microbiol 2004; 6: 401-410.

7 Cai WH, Gu B, Person S. Role of glycoprotein B of herpes simplex virus type 1 in viral entry and cell fusion. $J$ Virol 1988; 62: 2596-2604.

8 Fuller AO, Santos RE, Spear PG. Neutralizing antibodies specific for glycoprotein $\mathrm{H}$ of herpes simplex virus permit viral attachment to cells but prevent penetration. $J$ Virol 1989; 63: 3435-3443.

9 Roop C, Hutchinson L, Johnson DC. A mutant herpes simplex virus type 1 unable to express glycoprotein $\mathrm{L}$ cannot enter cells, and its particles lack glycoprotein H. $J$ Virol 1993; 67: 2285-2297.

10 DeLuca N, Bzik D, Person S, Snipes W. Early events in herpes simplex virus type 1 infection: photosensitivity of fluorescein isothiocyanate-treated virions. Proc Natl Acad Sci USA 1981; 78: 912-916.

11 Sodeik B, Ebersold MW, Helenius A. Microtubule-mediated transport of incoming herpes simplex virus 1 capsids to the nucleus. J Cell Biol 1997; 136: 1007-1021.

12 Roizman B, Knipe DM. Herpes Simplex Viruses and their Replication. Lippincott Williams \& Wilkins: Phladelphia, 2001.

13 Burton EA, Fink DJ, Glorioso JC. Gene delivery using herpes simplex virus vectors. DNA Cell Biol 2002; 21: 915-936.

14 Mocarski ES, Roizman B. Structure and role of the herpes simplex virus DNA termini in inversion, circularization and generation of virion DNA. Cell 1982; 31: 89-97.

15 Jacob RJ, Morse LS, Roizman B. Anatomy of herpes simplex virus DNA. XII. Accumulation of head-to-tail concatemers in nuclei of infected cells and their role in the generation of the four isomeric arrangements of viral DNA. J Virol 1979; 29: 448-457.

16 Steven AC, Spear PG. Herpesvirus Capsid Assembly and Envelopment. Oxford University Press: New York, 1997.

17 Homa FL, Brown JC. Capsid assembly and DNA packaging in herpes simplex virus. Rev Med Virol 1997; 7: 107-122.

18 Rixon FJ, Addison C, McGregor A, Macnab SJ, Nicholson $\mathrm{P}$, Preston VG et al. Multiple interactions control the intracellular localization of the herpes simplex virus type 1 capsid proteins. J Gen Virol 1996; 77(Part 9): 2251-2260.

19 Boehmer PE, Lehman IR. Herpes simplex virus DNA replication. Annu Rev Biochem 1997; 66: 347-384.

20 Deiss LP, Chou J, Frenkel N. Functional domains within the a sequence involved in the cleavage-packaging of herpes simplex virus DNA. J Virol 1986; 59: 605-618.

21 Taylor TJ, Brockman MA, McNamee EE, Knipe DM. Herpes simplex virus. Front Biosci 2002; 7: d752-d764.

22 Efstathiou S, Minson AC, Field HJ, Anderson JR, Wildy P. Detection of herpes simplex virus-specific DNA sequences in latently infected mice and in humans. $J$ Virol 1986; 57: 446-455.

23 Wagner EK, Bloom DC. Experimental investigation of herpes simplex virus latency. Clin Microbiol Rev 1997; 10: 419-443.

24 Croen KD, Ostrove JM, Dragovic LJ, Smialek JE, Straus SE. Latent herpes simplex virus in human trigeminal ganglia. Detection of an immediate early gene 'anti-sense' 
transcript by in situ hybridization. $N$ Engl J Med 1987; 317: $1427-1432$.

25 Rock DL, Nesburn AB, Ghiasi H, Ong J, Lewis TL, Lokensgard JR et al. Detection of latency-related viral RNAs in trigeminal ganglia of rabbits latently infected with herpes simplex virus type 1. J Virol 1987; 61: 3820-3826.

26 Spivack JG, Fraser NW. Detection of herpes simplex virus type 1 transcripts during latent infection in mice. $J$ Virol 1987; 61: 3841-3847.

27 Stevens JG, Wagner EK, Devi-Rao GB, Cook ML, Feldman LT. RNA complementary to a herpesvirus alpha gene mRNA is prominent in latently infected neurons. Science 1987; 235: 1056-1059.

28 Javier RT, Stevens JG, Dissette VB, Wagner EK. A herpes simplex virus transcript abundant in latently infected neurons is dispensable for establishment of the latent state. Virology 1988; 166: 254-257.

29 Sedarati F, Izumi KM, Wagner EK, Stevens JG. Herpes simplex virus type 1 latency-associated transcription plays no role in establishment or maintenance of a latent infection in murine sensory neurons. J Virol 1989; 63: 4455-4458.

30 Ho DY, Mocarski ES. Herpes simplex virus latent RNA (LAT) is not required for latent infection in the mouse. Proc Natl Acad Sci USA 1989; 86: 7596-7600.

31 Steiner I, Spivack JG, Lirette RP, Brown SM, MacLean AR, Subak-Sharpe JH et al. Herpes simplex virus type 1 latencyassociated transcripts are evidently not essential for latent infection. EMBO J 1989; 8: 505-511.

32 Kent JR, Kang W, Miller CG, Fraser NW. Herpes simplex virus latency-associated transcript gene function. $J$ Neurovirol 2003; 9: 285-290.

33 Bloom DC. HSV LAT and neuronal survival. Int Rev Immunol 2004; 23: 187-198.

34 Miller CS, Danaher RJ, Jacob RJ. Molecular aspects of herpes simplex virus I latency, reactivation, and recurrence. Crit Rev Oral Biol Med 1998; 9: 541-562.

35 Goodkin ML, Morton ER, Blaho JA. Herpes simplex virus infection and apoptosis. Int Rev Immunol 2004; 23: 141-172.

36 Hill A, Jugovic P, York I, Russ G, Bennink J, Yewdell J et al. Herpes simplex virus turns off the TAP to evade host immunity. Nature 1995; 375: 411-415.

37 Fruh K, Ahn K, Djaballah H, Sempe P, van Endert PM, Tampe $\mathrm{R}$ et al. A viral inhibitor of peptide transporters for antigen presentation. Nature 1995; 375: 415-418.

38 Matis J, Kudelova M. Early shutoff of host protein synthesis in cells infected with herpes simplex viruses. Acta Virol 2001; 45: 269-277.

39 Everett RD, Earnshaw WC, Findlay J, Lomonte P. Specific destruction of kinetochore protein CENP-C and disruption of cell division by herpes simplex virus immediate-early protein Vmw110. EMBO J 1999; 18: 1526-1538.

40 Advani SJ, Brandimarti R, Weichselbaum RR, Roizman B. The disappearance of cyclins $\mathrm{A}$ and $\mathrm{B}$ and the increase in activity of the $\mathrm{G}(2) / \mathrm{M}$-phase cellular kinase cdc2 in herpes simplex virus 1-infected cells require expression of the alpha22/U(S)1.5 and U(L)13 viral genes. $J$ Virol 2000; 74 : $8-15$.

41 Spencer CA, Dahmus ME, Rice SA. Repression of host RNA polymerase II transcription by herpes simplex virus type 1. J Virol 1997; 71: 2031-2040.

42 Sandri-Goldin RM. Properties of an HSV-1 regulatory protein that appears to impair host cell splicing. Infect Agents Dis 1994; 3: 59-67.

43 Chou J, Kern ER, Whitley RJ, Roizman B. Mapping of herpes simplex virus-1 neurovirulence to gamma 134.5, a gene nonessential for growth in culture. Science 1990; 250: $1262-1266$.

44 Chou J, Roizman B. The gamma 1(34.5) gene of herpes simplex virus 1 precludes neuroblastoma cells from triggering total shutoff of protein synthesis characteristic of programed cell death in neuronal cells. Proc Natl Acad Sci USA 1992; 89: $3266-3270$.

$45 \mathrm{He}$ B, Gross M, Roizman B. The gamma(1)34.5 protein of herpes simplex virus 1 complexes with protein phosphatase 1alpha to dephosphorylate the alpha subunit of the eukaryotic translation initiation factor 2 and preclude the shutoff of protein synthesis by double-stranded RNAactivated protein kinase. Proc Natl Acad Sci USA 1997; 94: 843-848.

46 Valyi-Nagy T, Fareed MU, O'Keefe JS, Gesser RM, MacLean AR, Brown SM et al. The herpes simplex virus type 1 strain $17+$ gamma 34.5 deletion mutant 1716 is avirulent in SCID mice. J Gen Virol 1994; 75(Part 8): 2059-2063.

47 Bolovan CA, Sawtell NM, Thompson RL. ICP34.5 mutants of herpes simplex virus type 1 strain $17 \mathrm{syn}+$ are attenuated for neurovirulence in mice and for replication in confluent primary mouse embryo cell cultures. J Virol 1994; 68: $48-55$.

48 Wakimoto H, Johnson PR, Knipe DM, Chiocca EA. Effects of innate immunity on herpes simplex virus and its ability to kill tumor cells. Gene Therapy 2003; 10: 983-990.

49 Wakimoto H, Fulci G, Tyminski E, Chiocca EA. Altered expression of antiviral cytokine mRNAs associated with cyclophosphamide's enhancement of viral oncolysis. Gene Therapy 2004; 11: 214-223.

50 Ikeda K, Ichikawa T, Wakimoto H, Silver JS, Deisboeck TS, Finkelstein D et al. Oncolytic virus therapy of multiple tumors in the brain requires suppression of innate and elicited antiviral responses. Nat Med 1999; 5: 881-887.

51 Morahan PS, Thomson TA, Kohl S, Murray BK. Immune responses to labial infection of $\mathrm{BALB} / \mathrm{c}$ mice with herpes simplex virus type 1. Infect Immun 1981; 32: 180-187.

52 Kapoor AK, Nash AA, Wildy P. Pathogenesis of herpes simplex virus in B cell-suppressed mice: the relative roles of cell-mediated and humoral immunity. J Gen Virol 1982; 61(Part 1): 127-131.

53 Kapoor AK, Nash AA, Wildy P, Phelan J, McLean CS, Field HJ. Pathogenesis of herpes simplex virus in congenitally athymic mice: the relative roles of cell-mediated and humoral immunity. J Gen Virol 1982; 60: 225-233.

54 Lopez C. Genetics of natural resistance to herpesvirus infections in mice. Nature 1975; 258: 152-153.

55 Lopez C. Resistance to HSV-1 in the mouse is governed by two major, independently segregating, non-H-2 loci. Immunogenetics 1980; 11: 87-92.

56 Koelle DM, Corey L. Recent progress in herpes simplex virus immunobiology and vaccine research. Clin Microbiol Rev 2003; 16: 96-113.

57 Kobelt D, Lechmann M, Steinkasserer A. The interaction between dendritic cells and herpes simplex virus-1. Curr Top Microbiol Immunol 2003; 276: 145-161.

58 Pollara G, Katz DR, Chain BM. The host response to herpes simplex virus infection. Curr Opin Infect Dis 2004; 17: 199-203.

59 Bowers WJ, Olschowka JA, Federoff HJ. Immune responses to replication-defective HSV-1 type vectors within the CNS: implications for gene therapy. Gene Therapy 2003; 10: 941-945. 
60 Stanberry LR. Clinical trials of prophylactic and therapeutic herpes simplex virus vaccines. Herpes 2004; 11(Suppl 3): 161A-169A.

61 Nash AA, Jayasuriya A, Phelan J, Cobbold SP, Waldmann H, Prospero T. Different roles for L3T4 + and Lyt $2+\mathrm{T}$ cell subsets in the control of an acute herpes simplex virus infection of the skin and nervous system. J Gen Virol 1987; 68(Part 3): 825-833.

62 Sethi KK, Omata Y, Schneweis KE. Protection of mice from fatal herpes simplex virus type 1 infection by adoptive transfer of cloned virus-specific and $\mathrm{H}-2$-restricted cytotoxic T lymphocytes. J Gen Virol 1983; 64(Part 2): 443-447.

63 Leung KN, Nash AA, Sia DY, Wildy P. Clonal analysis of T-cell responses to herpes simplex virus: isolation, characterization and antiviral properties of an antigen-specific helper T-cell clone. Immunology 1984; 53: 623-633.

64 Bonneau RH, Jennings SR. Modulation of acute and latent herpes simplex virus infection in C57BL/6 mice by adoptive transfer of immune lymphocytes with cytolytic activity. J Virol 1989; 63: 1480-1484.

65 Fraefel C, Jacoby DR, Breakefield XO. Herpes simplex virus type 1-based amplicon vector systems. Adv Virus Res 2000; 55: 425-451.

66 Link CJ, Hellrung DJ, Seregina T, Wang S. Eliciting hyperacute rejection as a tumor killing strategy. Herpes amplicon vector transfer of the alpha(1,3)galactosyltransferase gene. Adv Exp Med Biol 2000; 465: 217-227.

67 Federoff HJ, Halterman MW, Brooks AI. Use of the herpes amplicon system as a vehicle for somatic gene transfer. $A d v$ Drug Deliv Rev 1997; 27: 29-39.

68 Frenkel N, Singer O, Kwong AD. Minireview: the herpes simplex virus amplicon - a versatile defective virus vector. Gene Therapy 1994; 1(Suppl 1): S40-S46.

69 Sacks WR, Greene CC, Aschman DP, Schaffer PA. Herpes simplex virus type $1 \mathrm{ICP} 27$ is an essential regulatory protein. J Virol 1985; 55: 796-805.

70 DeLuca NA, McCarthy AM, Schaffer PA. Isolation and characterization of deletion mutants of herpes simplex virus type 1 in the gene encoding immediate-early regulatory protein ICP4. J Virol 1985; 56: 558-570.

71 Johnson PA, Miyanohara A, Levine F, Cahill T, Friedmann T. Cytotoxicity of a replication-defective mutant of herpes simplex virus type 1. J Virol 1992; 66: 2952-2965.

$72 \mathrm{Wu}$ N, Watkins SC, Schaffer PA, DeLuca NA. Prolonged gene expression and cell survival after infection by a herpes simplex virus mutant defective in the immediate-early genes encoding ICP4, ICP27, and ICP22. J Virol 1996; 70: 6358-6369.

73 Samaniego LA, Neiderhiser L, DeLuca NA. Persistence and expression of the herpes simplex virus genome in the absence of immediate-early proteins. J Virol 1998; 72: 3307-3320.

74 Krisky DM, Wolfe D, Goins WF, Marconi PC, Ramakrishnan $\mathrm{R}$, Mata $\mathrm{M}$ et al. Deletion of multiple immediate-early genes from herpes simplex virus reduces cytotoxicity and permits long-term gene expression in neurons. Gene Therapy 1998; 5: 1593-1603.

75 Ace CI, McKee TA, Ryan JM, Cameron JM, Preston CM. Construction and characterization of a herpes simplex virus type 1 mutant unable to transinduce immediate-early gene expression. J Virol 1989; 63: 2260-2269.

76 Preston CM, Mabbs R, Nicholl MJ. Construction and characterization of herpes simplex virus type 1 mutants with conditional defects in immediate early gene expression. Virology 1997; 229: 228-239.
77 Preston CM, Nicholl MJ. Repression of gene expression upon infection of cells with herpes simplex virus type 1 mutants impaired for immediate-early protein synthesis. J Virol 1997; 71: 7807-7813.

78 Farrell HE, McLean CS, Harley C, Efstathiou S, Inglis S, Minson AC. Vaccine potential of a herpes simplex virus type 1 mutant with an essential glycoprotein deleted. J Virol 1994; 68: 927-932.

79 Forrester A, Lipsey JR, Teitelbaum ML, DePaulo JR, Andrzejewski PL. Construction and properties of a mutant of herpes simplex virus type 1 with glycoprotein $\mathrm{H}$ coding sequences deleted. $J$ Virol 1992; 66: 341-348.

80 Gupta N. Current status of viral gene therapy for brain tumours. Expert Opin Invest Drugs 2000; 9: 713-726.

81 al-Rikabi AC, al-Sohaibani MO, Jamjoom A, al-Rayess MM. Metastatic deposits of a high-grade malignant glioma in cervical lymph nodes diagnosed by fine needle aspiration (FNA) cytology - case report and literature review. Cytopathology 1997; 8: 421-427.

82 Hsu E, Keene D, Ventureyra E, Matzinger MA, Jimenez C, Wang HS et al. Bone marrow metastasis in astrocytic gliomata. J Neurooncol 1998; 37: 285-293.

83 Spencer DM. Developments in suicide genes for preclinical and clinical applications. Curr Opin Mol Ther 2000; 2 433-440.

84 Field HJ, Wildy P. The pathogenicity of thymidine kinasedeficient mutants of herpes simplex virus in mice. $J \mathrm{Hyg}$ (London) 1978; 81: 267-277.

85 Chrisp CE, Sunstrum JC, Averill Jr DR, Levine M, Glorioso JC. Characterization of encephalitis in adult mice induced by intracerebral inoculation of herpes simplex virus type 1 (KOS) and comparison with mutants showing decreased virulence. Lab Invest 1989; 60: 822-830.

86 Efstathiou S, Kemp S, Darby G, Minson AC. The role of herpes simplex virus type 1 thymidine kinase in pathogenesis. J Gen Virol 1989; 70(Part 4): 869-879.

87 Moriuchi S, Oligino T, Krisky d, Marconi P, Fink D, Cohen $\mathrm{J}$ et al. Enhanced tumor cell killing in the presence of ganciclovir by herpes simplex virus type 1 vector-directed coexpression of human tumor necrosis factor-alpha and herpes simplex virus thymidine kinase. Cancer Res 1998; 58: 5731-5737.

88 Miyatake S, Martuza RL, Rabkin SD. Defective herpes simplex virus vectors expressing thymidine kinase for the treatment of malignant glioma. Cancer Gene Ther 1997; 4: 222-228.

89 Maria BL, Friedman T. Gene therapy for pediatric brain tumors. Semin Pediatr Neurol 1997; 4: 333-339.

90 Freeman SM, Whartenby KA, Freeman JL, Abboud CN, Marrogi AJ. In situ use of suicide genes for cancer therapy. Semin Oncol 1996; 23: 31-45.

91 van Dillen IJ, Mulder NH, Vaalburg W, de Vries EF, Hospers GA. Influence of the bystander effect on HSV-tk/ GCV gene therapy. A review. Curr Gene Ther 2002; 2: 307-322.

92 Nicholas TW, Read SB, Burrows FJ, Kruse CA. Suicide gene therapy with Herpes simplex virus thymidine kinase and ganciclovir is enhanced with connexins to improve gap junctions and bystander effects. Histol Histopathol 2003; 18: 495-507.

93 Naus CC, Bechberger JF, Zhang Y, Venance L, Yamasaki H, Juneja SC et al. Altered gap junctional communication, intercellular signaling, and growth in cultured astrocytes deficient in connexin43. $J$ Neurosci Res 1997; 49: 528-540. 
94 Yamasaki H, Krutovskikh V, Mesnil M, Tanaka T, ZaidanDagli ML, Omori Y. Role of connexin (gap junction) genes in cell growth control and carcinogenesis. CR Acad Sci III 1999; 322: 151-159.

95 Marconi P, Tamura M, Moriuchi S, Krisky DM, Niranjan A, Goins WF et al. Connexin 43-enhanced suicide gene therapy using herpesviral vectors. Mol Ther 2000; 1: 71-81.

96 Burton EA, Wechuck JB, Wendell SK, Goins WF, Fink DJ, Glorioso JC. Multiple applications for replication-defective herpes simplex virus vectors. Stem Cells 2001; 19: 358-377.

97 Rosenfeld MR, Meneses P, Dalmau J, Drobnjak M, Cordon-Cardo C, Kaplitt MG. Gene transfer of wild-type p53 results in restoration of tumor-suppressor function in a medulloblastoma cell line. Neurology 1995; 45: 1533-1539.

98 Hoshi M, Harada A, Kawase T, Uyemura K, Yazaki T. Antitumoral effects of defective herpes simplex virusmediated transfer of tissue inhibitor of metalloproteinases-2 gene in malignant glioma U87 in vitro: consequences for anticancer gene therapy. Cancer Gene Ther 2000; 7: 799-805.

99 Tung C, Federoff HJ, Brownlee M, Karpoff H, Weigel T, Brennan MF et al. Rapid production of interleukin-2secreting tumor cells by herpes simplex virus-mediated gene transfer: implications for autologous vaccine production. Hum Gene Ther 1996; 7: 2217-2224.

100 Kim SH, Carew JF, Kooby DA, Shields J, Entwisle C, Patel $\mathrm{S}$ et al. Combination gene therapy using multiple immunomodulatory genes transferred by a defective infectious single-cycle herpes virus in squamous cell cancer. Cancer Gene Ther 2000; 7: 1279-1285.

101 Toda M, Martuza RL, Kojima H, Rabkin SD. In situ cancer vaccination: an IL-12 defective vector/replicationcompetent herpes simplex virus combination induces local and systemic antitumor activity. $J$ Immunol 1998; 160: 4457-4464.

102 Kanno H, Hattori S, Sato H, Murata H, Huang FH, Hayashi A et al. Experimental gene therapy against subcutaneously implanted glioma with a herpes simplex virus-defective vector expressing interferon-gamma. Cancer Gene Ther 1999; 6: 147-154.

103 Toda M, Martuza RL, Rabkin SD. Tumor growth inhibition by intratumoral inoculation of defective herpes simplex virus vectors expressing granulocyte-macrophage colony-stimulating factor. Mol Ther 2000; 2: 324-329.

104 Niranjan A, Moriuchi S, Lunsford LD, Kondziolka D, Flickinger JC, Fellows W et al. Effective treatment of experimental glioblastoma by HSV vector-mediated TNF alpha and HSV-tk gene transfer in combination with radiosurgery and ganciclovir administration. Mol Ther 2000; 2: 114-120.

105 Niranjan A, Wolfe D, Tamura M, Soares MK, Krisky DM, Lunsford LD et al. Treatment of rat gliosarcoma brain tumors by HSV-based multigene therapy combined with radiosurgery. Mol Ther 2003; 8: 530-542.

106 Toda M, Martuza RL, Rabkin SD. Combination suicide/ cytokine gene therapy as adjuvants to a defective herpes simplex virus-based cancer vaccine. Gene Therapy 2001; 8 : 332-339.

107 Moriuchi S, glorioso JC, Maruno M, Izumoto S, Wolfe D, Huang $\mathrm{S}$ et al. Combination gene therapy for glioblastoma involving herpes simplex virus vector-mediated codelivery of mutant IkappaBalpha and HSV thymidine kinase. Cancer Gene Ther 2005; 5: 487-496.

108 Moriuchi S, Wolfe d, Tamura M, Yoshimine T, Miura F, Cohen JB et al. Double suicide gene therapy using a replication defective herpes simplex virus vector reveals reciprocal interference in a malignant glioma model. Gene Therapy 2002; 9: 584-591.

109 Dock G. Rabies virus vaccination in a patient with cervical carcinoma. Am J Med Sci 1904; 127: 563.

110 Bischoff JR, Kim DH, Williams A, heise C, Horn S, Muna $\mathrm{M}$ et al. An adenovirus mutant that replicates selectively in p53-deficient human tumor cells. Science 1996; 274: 373-376.

111 Nemunaitis J, Khuri F, Ganly I, Arseneau J, Posner M, Vokes E et al. Phase II trial of intratumoral administration of ONYX-015, a replication-selective adenovirus, in patients with refractory head and neck cancer. J Clin Oncol 2001; 19: 289-298.

112 McCormick F. Cancer-specific viruses and the development of ONYX-015. Cancer Biol Ther 2003; 2: S157-S160.

113 Reid T, Galanis E, Abbruzzese J, Sze D, Wein LM, Andrews $\mathbf{J}$ et al. Hepatic arterial infusion of a replicationselective oncolytic adenovirus (d11520): phase II viral, immunologic, and clinical endpoints. Cancer Res 2002; 62: 6070-6079.

114 Chiocca EA. Oncolytic viruses. Nat Rev Cancer 2002; 2: 938-950.

115 Kirn D. Oncolytic virotherapy as a novel treatment platform for cancer. Ernst Schering Research Foundation Workshop 2003 pp 89-105.

116 Nemunaitis J. Live viruses in cancer treatment. Oncology (Huntingt) 2002; 16: 1483-1492; discussion 1495-1487.

117 Nemunaitis J, Edelman J. Selectively replicating viral vectors. Cancer Gene Ther 2002; 9: 987-1000.

118 Shenk TE. Adenoviridae: The Viruses and their Replication. Lippincott Williams \& Wilkins: Philadelphia, 2001.

119 Dingwell KS, brunette CR, Hendricks RL, Tang O, Tang M, Rainbow AJ et al. Herpes simplex virus glycoproteins E and I facilitate cell-to-cell spread in vivo and across junctions of cultured cells. J Virol 1994; 68: 834-845.

120 Dingwell KS, Johnson DC. The herpes simplex virus gE-gI complex facilitates cell-to-cell spread and binds to components of cell junctions. $J$ Virol 1998; 72: 8933-8942.

121 De Clercq E, Andrei g, Snoeck R, De Bolle L, Naesens L, Degreve $\mathrm{B}$ et al. Acyclic/carbocyclic guanosine analogues as anti-herpesvirus agents. Nucleosides Nucleotides Nucleic Acids 2001; 20: 271-285.

122 De Clercq E. Antiviral drugs in current clinical use. J Clin Virol 2004; 30: 115-133.

123 Kirn D, Martuza RL, Zwiebel J. Replication-selective virotherapy for cancer: biological principles, risk management and future directions. Nat Med 2001; 7: 781-787.

124 Dobbelstein M. Replicating adenoviruses in cancer therapy. Curr Top Microbiol Immunol 2004; 273: 291-334.

125 Lou E. Oncolytic herpes viruses as a potential mechanism for cancer therapy. Acta Oncol 2003; 42: 660-671.

126 DeWeese TL, van der Poel H, Li S, Mikhak B, Drew R, Goemann $\mathrm{M}$ et al. A phase I trial of CV706, a replicationcompetent, PSA selective oncolytic adenovirus, for the treatment of locally recurrent prostate cancer following radiation therapy. Cancer Res 2001; 61: 7464-7472.

127 Rodriguez R, Schuur ER, Lim HY, Henderson GA, Simons JW, Henderson DR. Prostate attenuated replication competent adenovirus (ARCA) CN706: a selective cytotoxic for prostate-specific antigen-positive prostate cancer cells. Cancer Res 1997; 57: 2559-2563.

128 Curiel DT. Strategies to adapt adenoviral vectors for targeted delivery. Ann NY Acad Sci 1999; 886: 158-171. 
129 Goins WF, Wolfe D, Krisky DM, Bai Q, Burton EA, Fink DJ et al. Delivery using herpes simplex virus: an overview. Methods Mol Biol 2004; 246: 257-299.

130 Martuza RL, Malick A, Market JM, Ruffner KL, Coen DM. Experimental therapy of human glioma by means of a genetically engineered virus mutant. Science 1991; 252: 854-856.

131 Markert JM, Coen DM, Malick A, Mineta T, Martuza RL. Expanded spectrum of viral therapy in the treatment of nervous system tumors. J Neurosurg 1992; 77: 590-594.

132 Jia WW, McDermott M, Goldie J, Cynader M, Tan J, Tufaro F. Selective destruction of gliomas in immunocompetent rats by thymidine kinase-defective herpes simplex virus type 1. J Natl Cancer Inst 1994; 86: 1209-1215.

133 Boviatsis EJ, Scharf JM, Chase M, Harrington K, Kowall $\mathrm{NW}$, Breakefield XO et al. Antitumor activity and reporter gene transfer into rat brain neoplasms inoculated with herpes simplex virus vectors defective in thymidine kinase or ribonucleotide reductase. Gene Therapy 1994; 1: 323-331.

134 Kaplitt MG, Tjuvajev JG, Leib DA, Berk J, Pettigrew KD, Posner JB et al. Mutant herpes simplex virus induced regression of tumors growing in immunocompetent rats. J Neurooncol 1994; 19: 137-147.

135 Valyi-Nagy T, Gesser RM, Raengsakulrach B, Deshmane SL, Randazzo BP, Dillner AJ et al. A thymidine kinasenegative HSV-1 strain establishes a persistent infection in SCID mice that features uncontrolled peripheral replication but only marginal nervous system involvement. Virology 1994; 199: 484-490.

136 Cameron JM, McDougall I, Marsden HS, Preston VG, Ryan DM, Subak-Sharpe JH. Ribonucleotide reductase encoded by herpes simplex virus is a determinant of the pathogenicity of the virus in mice and a valid antiviral target. J Gen Virol 1988; 69(Part 10): 2607-2612.

137 Jacobson JG, Leib DA, Goldstein DJ, Bogard CL, Schaffer PA, Weller SK et al. A herpes simplex virus ribonucleotide reductase deletion mutant is defective for productive acute and reactivatable latent infections of mice and for replication in mouse cells. Virology 1989; 173: 276-283.

138 Mineta T, Rabkin SD, Martuza RL. Treatment of malignant gliomas using ganciclovir-hypersensitive, ribonucleotide reductase-deficient herpes simplex viral mutant. Cancer Res 1994; 54: 3963-3966.

139 Carroll NM, Chiocca EA, Takahashi K, Tanabe KK. Enhancement of gene therapy specificity for diffuse colon carcinoma liver metastases with recombinant herpes simplex virus. Ann Surg 1996; 224: 323-329; discussion 329-330.

140 Yoon SS, Carroll NM, Chiocca EA, Tanabe KK. Cancer gene therapy using a replication-competent herpes simplex virus type 1 vector. Ann Surg 1998; 228: 366-374.

141 Mineta T, Markert JM, Takamiya Y, Coen DM, Rabkin SD, Martuza RL. CNS tumor therapy by attenuated herpes simplex viruses. Gene Therapy 1994; 1(Suppl 1): S78.

142 Jacobs A, Tjuvajev JG, Dubrovin M, Akhurst T, Balatoni $\mathrm{J}$, Beattie B et al. Positron emission tomography-based imaging of transgene expression mediated by replicationconditional, oncolytic herpes simplex virus type 1 mutant vectors in vivo. Cancer Res 2001; 61: 2983-2995.

143 Kasuya H, Nishiyama Y, Nomoto S, Hosono J, Takeda S, Nakao A. Intraperitoneal delivery of hrR3 and ganciclovir prolongs survival in mice with disseminated pancreatic cancer. J Surg Oncol 1999; 72: 136-141.

144 Yoon SS, Nakamura H, Carroll NM, Bode BP, Chiocca EA, Tanabe KK. An oncolytic herpes simplex virus type 1 selectively destroys diffuse liver metastases from colon carcinoma. FASEB J 2000; 14: 301-311.

145 Pawlik TM, Nakamura H, Yoon SS, Mullen JT, Chandrasekhar S, Chiocca EA et al. Oncolysis of diffuse hepatocellular carcinoma by intravascular administration of a replication-competent, genetically engineered herpesvirus. Cancer Res 2000; 60: 2790-2795.

146 Ikeda K, Wakimoto H, Ichikawa T, Jhung S, Hochberg FH, Louis DN et al. Complement depletion facilitates the infection of multiple brain tumors by an intravascular, replication-conditional herpes simplex virus mutant. $J$ Virol 2000; 74: 4765-4775.

147 Spivack JG, Fareed MU, Valyi-Nagy T, Nash TC, O'Keefe JS, Gesser RM et al. Replication, establishment of latent infection, expression of the latency-associated transcripts and explant reactivation of herpes simplex virus type 1 gamma 34.5 mutants in a mouse eye model. J Gen Virol 1995; 76(Part 2): 321-332.

148 McKie EA, MacLean AR, Lewis AD, Cruickshank G, Rampling R, Barnett SC et al. Selective in vitro replication of herpes simplex virus type 1 (HSV-1) ICP34.5 null mutants in primary human CNS tumours - evaluation of a potentially effective clinical therapy. Br J Cancer 1996; 74: 745-752.

149 Kucharczuk JC, Randazzo B, Chang MY, Amin KM, Elshami AA, Sterman DH et al. Use of a 'replicationrestricted' herpes virus to treat experimental human malignant mesothelioma. Cancer Res 1997; 57: 466-471.

150 Randazzo BP, Bhat MG, Kesari S, Fraser NW, Brown SM. Treatment of experimental subcutaneous human melanoma with a replication-restricted herpes simplex virus mutant. J Invest Dermatol 1997; 108: 933-937.

151 Randazzo BP, Kesari S, Gesser RM, Alsop D, Ford JC, Brown SM et al. Treatment of experimental intracranial murine melanoma with a neuroattenuated herpes simplex virus 1 mutant. Virology 1995; 211: 94-101.

152 Kesari S, Randazzo BP, Valyi-Nagy T, Huang QS, Brown SM, MacLean AR et al. Therapy of experimental human brain tumors using a neuroattenuated herpes simplex virus mutant. Lab Invest 1995; 73: 636-648.

153 Chambers R, Gillespie GY, Soroceanu L, Andreansky S, Chatterjee $\mathrm{S}$, Chou $\mathrm{J}$ et al. Comparison of genetically engineered herpes simplex viruses for the treatment of brain tumors in a SCID mouse model of human malignant glioma. Proc Natl Acad Sci USA 1995; 92: 1411-1415.

154 Lasner TM, Kesari S, Brown SM, Lee VM, Fraser NW, Trojanowski JQ. Therapy of a murine model of pediatric brain tumors using a herpes simplex virus type-1 ICP34.5 mutant and demonstration of viral replication within the CNS. J Neuropathol Exp Neurol 1996; 55: 1259-1269.

155 Andreansky SS, He B, Gillespie GY, Soroceanu L, Market $\mathbf{J}$, Chou $\mathbf{J}$ et al. The application of genetically engineered herpes simplex viruses to the treatment of experimental brain tumors. Proc Natl Acad Sci USA 1996; 93: 11313-11318.

156 Coukos G, Makrigiannakis A, Kang EH, Rubin SC, Albelda SM, Molnar-Kimber KL. Oncolytic herpes simplex virus-1 lacking ICP34.5 induces p53-independent death and is efficacious against chemotherapy-resistant ovarian cancer. Clin Cancer Res 2000; 6: 3342-3353.

157 Lambright ES, Caparrelli DJ, Abbas AE, Toyoizumi T, Coukos G, Molnar-Kimber KL et al. Oncolytic therapy using a mutant type-1 herpes simplex virus and the role of the immune system. Ann Thorac Surg 1999; 68: 1756-1760; discussion 1761-1752. 
158 Rampling R, Cruickshank G, Papanastassiou V, Nicoll J, Hadley D, Brennan D et al. Toxicity evaluation of replication-competent herpes simplex virus (ICP 34.5 null mutant 1716) in patients with recurrent malignant glioma. Gene Therapy 2000; 7: 859-866.

159 Papanastassiou V, Rampling R, Fraser M, Petty R, Hadley D, Nicoll $\mathbf{J}$ et al. The potential for efficacy of the modified (ICP 34.5(-)) herpes simplex virus HSV1716 following intratumoural injection into human malignant glioma: a proof of principle study. Gene Therapy 2002; 9: 398-406.

160 Harrow S, Papanstassiou V, Harland J, Mabbs R, Petty R, Fraser M et al. HSV1716 injection into the brain adjacent to tumour following surgical resection of high-grade glioma: safety data and long-term survival. Gene Ther 2004; 11: $1648-1658$.

161 Kesari S, Lasner TM, Balsara KR, Randazzo BP, Lee VM, Trojanowski JQ et al. A neuroattenuated ICP34.5-deficient herpes simplex virus type 1 replicates in ependymal cells of the murine central nervous system. J Gen Virol 1998; 79(Part 3): 525-536.

162 McMenamin MM, Byrnes AP, Pike FG, Charlton HM, Coffin RS, Latchman DS et al. Potential and limitations of a gamma 34.5 mutant of herpes simplex 1 as a gene therapy vector in the CNS. Gene Therapy 1998; 5: 594-604.

163 Lasner TM, Tal-Singer R, Kesari S, Lee VM, Trojanowski JQ, Fraser NW. Toxicity and neuronal infection of a HSV-1 ICP34.5 mutant in nude mice. J Neurovirol 1998; 4: $100-105$.

164 Pyles RB, Santoro IM, Groden J, Parysek LM. A novel multiply-mutated HSV-1 strain for the treatment of human brain tumors. Hum Gene Ther 1997; 8: 533-544.

165 Kramm CM, Chase M, Herrlinger U, Jacobs A, Pechan PA, Rainov NG et al. Therapeutic efficiency and safety of a second-generation replication-conditional HSV1 vector for brain tumor gene therapy. Hum Gene Ther 1997; 8: 2057-2068.

166 Mineta T, Rabkin SD, Yazaki T, Hunter WD, Martuza RL. Attenuated multi-mutated herpes simplex virus-1 for the treatment of malignant gliomas. Nat Med 1995; 1: 938-943.

167 Hunter WD, Martuza RL, Feigenbaum F, Todo T, Mineta $\mathrm{T}$, Yazaki T et al. Attenuated, replication-competent herpes simplex virus type 1 mutant G207: safety evaluation of intracerebral injection in nonhuman primates. $J$ Virol 1999; 73: 6319-6326.

168 Sundaresan P, Hunter WD, Martuza RL, Rabkin SD. Attenuated, replication-competent herpes simplex virus type 1 mutant G207: safety evaluation in mice. $J$ Virol 2000; 74: 3832-3841.

169 Todo T, Feigenbaum F, Rabkin SD, Lakeman F, Newsome JT, Johnson PA et al. Viral shedding and biodistribution of G207, a multimutated, conditionally replicating herpes simplex virus type 1 , after intracerebral inoculation in aotus. Mol Ther 2000; 2: 588-595.

170 Varghese S, Newsome JT, Rabkin SD, McGeagh K, Mahoney D, Nielsen $\mathrm{P}$ et al. Preclinical safety evaluation of G207, a replication-competent herpes simplex virus type 1 , inoculated intraprostatically in mice and nonhuman primates. Hum Gene Ther 2001; 12: 999-1010.

171 Kooby DA, Carew JF, Halterman MW, Mack JE, Bertino JR, Blumgart LH et al. Oncolytic viral therapy for human colorectal cancer and liver metastases using a multi-mutated herpes simplex virus type-1 (G207). FASEB J 1999; 13: $1325-1334$
172 Toda M, Rabkin SD, Kojima H, Martuza RL. Herpes simplex virus as an in situ cancer vaccine for the induction of specific anti-tumor immunity. Hum Gene Ther 1999; 10: 385-393.

173 Bennett JJ, Kooby DA, Delman K, McAuliffe P, Halterman MW, Federoff $\mathrm{H}$ et al. Antitumor efficacy of regional oncolytic viral therapy for peritoneally disseminated cancer. $J$ Mol Med 2000; 78: 166-174.

174 Coukos G, Makrigiannakis A, Montas S, Kaiser LR, Toyozumi T, Benjamin I et al. Multi-attenuated herpes simplex virus-1 mutant G207 exerts cytotoxicity against epithelial ovarian cancer but not normal mesothelium and is suitable for intraperitoneal oncolytic therapy. Cancer Gene Ther 2000; 7: 275-283.

175 Blank SV, Rubin SC, Coukos G, Amin KM, Albelda SM, Molnar-Kimber KL. Replication-selective herpes simplex virus type 1 mutant therapy of cervical cancer is enhanced by low-dose radiation. Hum Gene Ther 2002; 13: 627-639.

176 Varghese S, Rabkin SD. Oncolytic herpes simplex virus vectors for cancer virotherapy. Cancer Gene Ther 2002; 9: 967-978.

177 Iizuka Y, Suzuki A, Kawakami Y, Toda M. Augmentation of antitumor immune responses by multiple intratumoral inoculations of replication-conditional HSV and interleukin-12. J Immunother 2004; 27: 92-98.

178 Chahlavi A, Rabkin S, Todo T, Sundaresan P, Martuza R. Effect of prior exposure to herpes simplex virus 1 on viral vector-mediated tumor therapy in immunocompetent mice. Gene Therapy 1999; 6: 1751-1758.

179 Delman KA, Bennett JJ, Zager JS, Burt BM, McAuliffe PF, Petrowsky $\mathrm{H}$ et al. Effects of preexisting immunity on the response to herpes simplex-based oncolytic viral therapy. Hum Gene Ther 2000; 11: 2465-2472.

180 Todo T, Rabkin SD, Sundaresan P, Wu A, Meehan KR, Herscowitz $\mathrm{HB}$ et al. Systemic antitumor immunity in experimental brain tumor therapy using a multimutated, replication-competent herpes simplex virus. Hum Gene Ther 1999; 10: 2741-2755.

181 Toda M, Iizuka Y, Kawase T, Uyemura K, Kawakami Y. Immuno-viral therapy of brain tumors by combination of viral therapy with cancer vaccination using a replicationconditional HSV. Cancer Gene Ther 2002; 9: 356-364.

182 Endo T, Toda M, Watanabe M, Iizuka Y, Kubota T, Kitajima $\mathrm{M}$ et al. In situ cancer vaccination with a replication-conditional $\mathrm{HSV}$ for the treatment of liver metastasis of colon cancer. Cancer Gene Ther 2002; 9: $142-148$.

183 Toda M. Immuno-viral therapy as a new approach for the treatment of brain tumors. Drug News Perspect 2003; 16: 223-229.

184 Markert JM, Medlock MD, Rabkin SD, Gillespie GY, Todo T, Hunter WD et al. Conditionally replicating herpes simplex virus mutant, G207 for the treatment of malignant glioma: results of a phase I trial. Gene Therapy 2000; 7: 867-874.

185 Meignier B, Longnecker R, Roizman B. In vivo behavior of genetically engineered herpes simplex viruses R7017 and R7020: construction and evaluation in rodents. J Infect Dis 1988; 158: 602-614.

186 Meignier B, Martin B, Whitley RJ, Roizman B. In vivo behavior of genetically engineered herpes simplex viruses R7017 and R7020. II. Studies in immunocompetent and immunosuppressed owl monkeys (Aotus trivirgatus). J Infect Dis 1990; 162: 313-321. 
187 Advani SJ, Chung SM, yan SY, Gillespie GY, Markert JM, Whitley RJ et al. Replication-competent, nonneuroinvasive genetically engineered herpes virus is highly effective in the treatment of therapy-resistant experimental human tumors. Cancer Res 1999; 59: 2055-2058.

188 Chung SM, Advani SJ, Bradley JD, Kataoka Y, Vashistha $\mathrm{K}$, Yan SY et al. The use of a genetically engineered herpes simplex virus (R7020) with ionizing radiation for experimental hepatoma. Gene Therapy 2002; 9: 75-80.

189 McAuliffe PF, Jarnagin WR, Johnson P, Delman KA, Federoff $\mathrm{H}$, Fong Y. Effective treatment of pancreatic tumors with two multimutated herpes simplex oncolytic viruses. J Gastrointest Surg 2000; 4: 580-588.

190 Cozzi PJ, Malhotra S, McAuliffe P, Kooby DA, Federoff HJ, Huryk B et al. Intravesical oncolytic viral therapy using attenuated, replication-competent herpes simplex viruses G207 and Nv1020 is effective in the treatment of bladder cancer in an orthotopic syngeneic model. FASEB J 2001; 15: $1306-1308$.

191 Cozzi PJ, Burke PB, Bhargav A, Heston WD, Huryk B, Scardino PT et al. Oncolytic viral gene therapy for prostate cancer using two attenuated, replication-competent, genetically engineered herpes simplex viruses. Prostate 2002; 53: 95-100.

192 Bennett JJ, Delman KA, Burt BM, Mariotti A. Comparison of safety, delivery, and efficacy of two oncolytic herpes viruses (G207 and NV1020) for peritoneal cancer. Cancer Gene Ther 2002; 9: 935-945.

193 Delman KA, Zager JS, Bhargava A, Petrowsky H, Malhotra S, Ebright MI et al. Effect of murine liver cell proliferation on herpes viral behavior: implications for oncolytic viral therapy. Hepatology 2004; 39: 1525-1532.

194 Fong Y, Kemeny N, Jarnagin W, Stanziale S, Guilfoyle B, Susani $\mathrm{N}$ et al. Phase 1 study of a replication-competent herpes simplex oncolytic virus for treatment of hepatic colorectal metastases. ASCO Annual Meeting 2002.

195 Todo T, Martuza RL, Rabkin SD, Johnson PA. Oncolytic herpes simplex virus vector with enhanced MHC class I presentation and tumor cell killing. Proc Natl Acad Sci USA 2001; 98: 6396-6401.

196 Chung RY, Saeki Y, Chiocca EA. B-myb promoter retargeting of herpes simplex virus gamma34.5 genemediated virulence toward tumor and cycling cells. $J$ Virol 1999; 73: 7556-7564.

197 Bennett JD, Farlie PG, Watson RJ. E2F binding is required but not sufficient for repression of B-myb transcription in quiescent fibroblasts. Oncogene 1996; 13: 1073-1082.

198 Nakamura H, Kasuya H, Mullen JT, Yoon SS, Pawlik TM, Chandrasekhar S et al. Regulation of herpes simplex virus gamma(1)34.5 expression and oncolysis of diffuse liver metastases by Myb34.5. J Clin Invest 2002; 109: 871-882.

199 Hinoda Y, Ikematsu Y, Horinochi M, Sato S, Yamamoto K, Nakano T et al. Increased expression of MUC1 in advanced pancreatic cancer. J Gastroenterol 2003; 38: 1162-1166.

200 Mullen JT, Kasuya H, Yoon SS, Carroll NM, Pawlik TM, Chandrasekhar S et al. Regulation of herpes simplex virus 1 replication using tumor-associated promoters. Ann Surg 2002; 236: 502-512; discussion 512-503.

201 Kasuya H, Pawlik TM, Mullen JT, Donahue JM, Nakamura $\mathrm{H}$, Chandrasekhar $\mathrm{S}$ et al. Selectivity of an oncolytic herpes simplex virus for cells expressing the DF3/ MUC1 antigen. Cancer Res 2004; 64: 2561-2567.

202 Miyatake S, Iyer A, Martuza RL, Rabkin SD. Transcriptional targeting of herpes simplex virus for cell-specific replication. J Virol 1997; 71: 5124-5132.
203 Miyatake S. Gene therapy using tissue-specific replication competent HSV. Hum Cell 2002; 15: 130-137.

204 Yamamura H, Hashio M, Noguchi M, Sugenoya Y, Osakada M, Hirano $\mathrm{N}$ et al. Identification of the transcriptional regulatory sequences of human calponin promoter and their use in targeting a conditionally replicating herpes vector to malignant human soft tissue and bone tumors. Cancer Res 2001; 61: 3969-3977.

205 Everts M, Curiel DT. Transductional targeting of adenoviral cancer gene therapy. Curr Gene Ther 2004; 4: 337-346.

206 Laquerre S, Anderson DB, Stolz DB, Glorioso JC. Recombinant herpes simplex virus type 1 engineered for targeted binding to erythropoietin receptor-bearing cells. J Virol 1998; 72: 9683-9697.

207 Argnani R, Boccafogli L, Marconi PC, Manservigi R. Specific targeted binding of herpes simplex virus type 1 to hepatocytes via the human hepatitis B virus preS1 peptide. Gene Therapy 2004; 11: 1087-1098.

208 Zhou G, Ye GJ, Debinski W, Roizman B. Engineered herpes simplex virus 1 is dependent on IL13Ralpha 2 receptor for cell entry and independent of glycoprotein D receptor interaction. Proc Natl Acad Sci USA 2002; 99: 15124-15129.

209 Ford AC, Grandis JR. Targeting epidermal growth factor receptor in head and neck cancer. Head Neck 2003; 25: $67-73$.

210 Gosselin MA, Lee RJ. Folate receptor-targeted liposomes as vectors for therapeutic agents. Biotechnol Annu Rev 2002; 8: $103-131$.

211 Assimakopoulos D, Kolettas E, Patrikakos G, Evangelou A. The role of CD44 in the development and prognosis of head and neck squamous cell carcinomas. Histol Histopathol 2002; 17: 1269-1281.

212 Mullen JT, Donahue JM, Chandrasekhar S, Yoon SS, Liu $\mathrm{W}$, Ellis LM et al. Oncolysis by viral replication and inhibition of angiogenesis by a replication-conditional herpes simplex virus that expresses mouse endostatin. Cancer 2004; 101: 869-877.

213 Andreansky S, He B, van Cott J, McGhee J, Market JM, Gillespie GY et al. Treatment of intracranial gliomas in immunocompetent mice using herpes simplex viruses that express murine interleukins. Gene Therapy 1998; 5: 121-130.

214 Parker JN, Gillespie GY, Love CE, Randall S, Whitley RJ, Markert JM. Engineered herpes simplex virus expressing IL-12 in the treatment of experimental murine brain tumors. Proc Natl Acad Sci USA 2000; 97: 2208-2213.

215 Bennett JJ, Malhotra S, Wong RJ, Delman K, Zager J, StLouis $\mathrm{M}$ et al. Interleukin 12 secretion enhances antitumor efficacy of oncolytic herpes simplex viral therapy for colorectal cancer. Ann Surg 2001; 233: 819-826.

216 Jarnagin WR, Zager JS, Klimstra D, Delman KA, Malhotra S, Elbright $\mathrm{M}$ et al. Neoadjuvant treatment of hepatic malignancy: an oncolytic herpes simplex virus expressing IL-12 effectively treats the parent tumor and protects against recurrence-after resection. Cancer Gene Ther 2003; 10: 215-223.

217 Wong RJ, Chan MK, Yu Z, Kim TH, Bhargava A, Stiles $\mathrm{BM}$ et al. Effective intravenous therapy of murine pulmonary metastases with an oncolytic herpes virus expressing interleukin 12. Clin Cancer Res 2004; 10: 251-259.

218 Wong RJ, Chan MK, Yu Z, Ghossein RA, Ngai I, Adusumilli PS et al. Angiogenesis inhibition by an oncolytic herpes virus expressing interleukin 12. Clin Cancer Res 2004; 10: 4509-4516. 
219 Wong RJ, Patel SG, Kim S, DeMatteo RP, Malhotra S, Bennett JJ et al. Cytokine gene transfer enhances herpes oncolytic therapy in murine squamous cell carcinoma. Hum Gene Ther 2001; 12: 253-265.

220 Carew JF, Kooby DA, Halterman MW, Kim SH, Federoff HJ, Fong Y. A novel approach to cancer therapy using an oncolytic herpes virus to package amplicons containing cytokine genes. Mol Ther 2001; 4: 250-256.

221 Zager JS, Delman KA, Malhotra S, Ebright MI, Bennett JJ, Kates $\mathrm{T}$ et al. Combination vascular delivery of herpes simplex oncolytic viruses and amplicon mediated cytokine gene transfer is effective therapy for experimental liver cancer. Mol Med 2001; 7: 561-568.

222 Liu BL, Robinson M, Han ZQ, Branston RH, English C, Reay $\mathrm{P}$ et al. ICP34.5 deleted herpes simplex virus with enhanced oncolytic, immune stimulating, and anti-tumour properties. Gene Therapy 2003; 10: 292-303.

223 Coffin RS, Liu B, Han Z, Simpson G, Hu J, Coombes C et al. OncoVEX: A family of oncolytic herpes simplex viruses optimised for therapeutic use. ASCO Annual Meeting: Orlando, FL. 2004.

224 Nakamura H, Mullen JT, Chandrasekhar S, Pawlik TM, Yoon SS, Tanabe KK. Multimodality therapy with a replication-conditional herpes simplex virus 1 mutant that expresses yeast cytosine deaminase for intratumoral conversion of 5-fluorocytosine to 5-fluorouracil. Cancer Res 2001; 61: 5447-5452.

225 Chase M, Chung RY, Chiocca EA. An oncolytic viral mutant that delivers the CYP2B1 transgene and augments cyclophosphamide chemotherapy. Nat Biotechnol 1998; 16: 444-448.

226 Ichikawa T, Petros WP, Ludeman SM, Fangmeier J, Hochberg FH, Colvin OM et al. Intraneoplastic polymerbased delivery of cyclophosphamide for intratumoral bioconversion by a replicating oncolytic viral vector. Cancer Res 2001; 61: 864-868.

227 Pawlik TM, Nakamura H, Mullen JT, Kasuya H, Yoon SS, Chandrasekhar $\mathrm{S}$ et al. Prodrug bioactivation and oncolysis of diffuse liver metastases by a herpes simplex virus 1 mutant that expresses the CYP2B1 transgene. Cancer 2002; 95: 1171-1181.

228 Aghi M, Chou TC, Suling K, Breakefield XO, Chiocca EA. Multimodal cancer treatment mediated by a replicating oncolytic virus that delivers the oxazaphosphorine/rat cytochrome $P 4502 \mathrm{~B} 1$ and ganciclovir/herpes simplex virus thymidine kinase gene therapies. Cancer Res 1999; 59: 3861-3865.

229 Cinatl Jr J, Cinatl J, Michaelis M, Kabickova H, Kotchetkov R, Vogel JU et al. Potent oncolytic activity of multimutated herpes simplex virus G207 in combination with vincristine against human rhabdomyosarcoma. Cancer Res 2003; 63: 1508-1514.

230 Bennett JJ, Adusumilli P, Petrowsky H, Burt BM, Roberts G, Delman KA et al. Up-regulation of GADD34 mediates the synergistic anticancer activity of mitomycin $\mathrm{C}$ and a gamma134.5 deleted oncolytic herpes virus (G207). FASEB $J$ 2004; 18: 1001-1003.

231 Post DE, Fulci G, Chiocca EA, Van Meir EG. Replicative oncolytic herpes simplex viruses in combination cancer therapies. Curr Gene Ther 2004; 4: 41-51.

232 Stanziale SF, Petrowsky H, Joe JK, Roberts GD, Zager JS, Gusani NJ et al. Ionizing radiation potentiates the antitumor efficacy of oncolytic herpes simplex virus G207 by upregulating ribonucleotide reductase. Surgery 2002; 132: 353-359.

233 Toyoizumi T, Mick R, Abbas AE, Kang EH, Kaiser LR, Molnar-Kimber KL. Combined therapy with chemotherapeutic agents and herpes simplex virus type 1 ICP34.5 mutant (HSV-1716) in human non-small cell lung cancer. Hum Gene Ther 1999; 10: 3013-3029.

234 Spear MA, Sun F, Eling DJ, Gilpin E, Kipps TJ, Chiocca EA et al. Cytotoxicity, apoptosis, and viral replication in tumor cells treated with oncolytic ribonucleotide reductasedefective herpes simplex type 1 virus (hrR3) combined with ionizing radiation. Cancer Gene Ther 2000; 7: 1051-1059.

235 Advani SJ, Sibley GS, Song PY, Hallahan DE, Kataoka Y, Roizman B et al. Enhancement of replication of genetically engineered herpes simplex viruses by ionizing radiation: a new paradigm for destruction of therapeutically intractable tumors. Gene Therapy 1998; 5: 160-165.

236 Bradley JD, Kataoka Y, Advani S, Chung SM, Arani RB, Gillespie GY et al. Ionizing radiation improves survival in mice bearing intracranial high-grade gliomas injected with genetically modified herpes simplex virus. Clin Cancer Res 1999; 5: 1517-1522.

237 Jorgensen TJ, Katz S, Wittmack EK, Varghese S, Todo T, Rabkin SD et al. Ionizing radiation does not alter the antitumor activity of herpes simplex virus vector G207 in subcutaneous tumor models of human and murine prostate cancer. Neoplasia 2001; 3: 451-456.

238 Wang Q, Guo J, Jia W. Intracerebral recombinant HSV-1 vector does not reactivate latent HSV-1. Gene Therapy 1997; 4: 1300-1304.

239 Speck PG, Efstathiou S, Minson AC. In vivo complementation studies of a glycoprotein H-deleted herpes simplex virus-based vector. J Gen Virol 1996; 77(Part 10): $2563-2568$.

240 Villarreal EC. Current and potential therapies for the treatment of herpes-virus infections. Prog Drug Res 2003; 60: $263-307$.

241 Gatto B. Monoclonal antibodies in cancer therapy. Curr Med Chem Anti-Cancer Agents 2004; 4: 411-414.

242 Taneja S, MacGregor J, Markus S, Ha S, Mohr I. Enhanced antitumor efficacy of a herpes simplex virus mutant isolated by genetic selection in cancer cells. Proc Natl Acad Sci USA 2001; 98: 8804-8808.

243 Yan W, Kitzes G, Dormishian F, Hawkins L, SampsonJohannes A, Watanabe $\mathrm{J}$ et al. Developing novel oncolytic adenoviruses through bioselection. J Virol 2003; 77: 2640-2650.

244 MacKie RM, Stewart B, Brown SM. Intralesional injection of herpes simplex virus 1716 in metastatic melanoma. Lancet 2001; 357: 525-526.

245 Andreansky S, Soroceanu L, flotte ER, Chou J, Markert JM, Gillespie GY et al. Evaluation of genetically engineered herpes simplex viruses as oncolytic agents for human malignant brain tumors. Cancer Res 1997; 57: 1502-1509.

246 Nakao A, Kimata H, Imai T, Kikumori T, Teshigahara O, Nagasaka $\mathrm{T}$ et al. Intratumoral injection of herpes simplex virus HF10 in recurrent breast cancer. Ann Oncol 2004; 15 : 988-989.

247 Takakuwa H, Goshima F, Nozawa N, Yoshikawa T, Kimata H, Nakao A et al. Oncolytic viral therapy using a spontaneously generated herpes simplex virus type 1 variant for disseminated peritoneal tumor in immunocompetent mice. Arch Virol 2003; 148: 813-825. 